Article

\title{
The Historical Earthworks of the Warsaw Citadel
}

\author{
Marek Wyjadłowski *®D, Janusz Kozubal ${ }^{(\mathbb{D}}$ and Wojciech Damsz \\ Departament of Civil Engineering, Wroclaw University of Science and Technology, 50-370 Wrocław, Poland; \\ janusz.kozubal@pwr.edu.pl (J.K.); wojciech.damsz@gmail.com (W.D.) \\ * Correspondence: marek.wyjadlowski@pwr.edu.pl
}

Received: 30 June 2020; Accepted: 3 September 2020; Published: 17 September 2020

\begin{abstract}
In this study, we analyzed the methods and technologies used for constructing earthworks and military engineering in the latter period before the industrial revolution in Poland. The research object, the Warsaw Citadel, is a source of knowledge about military heritage from the aspect of conservation and protection of specific engineering achievements, which were dictated by early Russian geopolitical doctrine. Within the framework of the ongoing project of material heritage protection and popularization of history, the fortress has been transformed into a modern museum building. The new symbolic message of architecture was redefined, leaving behind the gloomy dominance elements in the scenery of the nearby city. In this study, reception tests of ground anchors were used for analysis. They were treated as a tool to determine the heterogeneity of fortification of historical earthworks. In the presented calculation procedure, limitations in the availability of geotechnical tests were overcome. Geological terrain layout and embankment excavation technology significantly impacted their quality and reliability. Currently, the embankments are slashed with anchored retaining walls. Ground anchors were used at short distances and were tested according to the national standard procedures. The results of the load tests are based on the physical properties of the subsoil, the conditions of contact with the supporting elements of the anchors, and the material properties. The soil interaction with the anchors is described using a rheological model, the constants of which were obtained using a fractional derivative model. The spatial variability of the rheological model parameters is presented using theoretical semivariograms matching the empirical data. The semivariograms explain the spatial correlation of the tested constants of the rheological model of the substrate with the anchors. The results of non-destructive testing were influenced by factors such as time and consolidation processes. The obtained results allowed us to directly draw conclusions about the repetitiveness of embankment features and indirectly about the quality of their construction.
\end{abstract}

Keywords: creep; anchors; earthworks; geoengineering history; fractional derivative model

\section{Introduction}

Historical fortifications are today's monuments of civil engineering and architectural art. Militarily useless castles, forts, and barracks are symbols of past construction achievements and provide pretext to history. The monumental objects are often unique and, regardless of the changing architectural forms, overwhelm the surroundings with their presence [1]. The modern approach to fortification forms should consider their civilizational, historical, military, and archaeological significance [2-5]. In this study, the analyzed object was the Warsaw Citadel (Figures $1 \mathrm{~b}$ and 2). It was built as a huge fortress, as evidenced by its dimensions: The perimeter along the line of walls is $2680 \mathrm{~m}$, the area within the embankments is $10.5 \mathrm{ha}$, and the total area, including the moat and embankments, is $67 \mathrm{ha}$. This large field was capable of holding 16,000 Russian troops at its peak. Shortly after construction, the military elements inside the Warsaw Citadel were built, including 104 prison casemates for up to 3000 
prisoners [6,7]. The history of the establishment of the Warsaw Citadel is as follows: After the third partition of Poland in 1795, the Polish state had been erased from the political map of Europe for more than 120 years (Figure 1a). At this time, there was no Polish territory under Polish administration, and even the name of Poland was forbidden. The outcomes of the period of the Napoleonic wars fell short of Polish expectations, although they resulted in some important profits, e.g., establishment of the Duchy of Warsaw. In 1814, when the Congress of Vienna started to discuss a new shape of the map of Europe, the Duchy of Warsaw still existed, occupied by Russian troops but under Polish administration. According to the decision of the Congress of Vienna, the Duchy of Warsaw was partitioned. A part of the Duchy under the name of the Kingdom of Poland was given to Tsar Alexander I. The revolutions in Paris and in Brussels in 1830 undermined the political order of Europe established at the Congress of Vienna. Tsar Alexander I ordered a mobilization of some Russian corps in the Empire and of the Polish Army in the Kingdom with intention of waging a war against France and Belgium to defend the continent against the revolution. A revolution also broke out in Warsaw on the night of 29-30 November 1830 to prevent Polish troops from being led against the revolution in West Europe. Most units of the Polish Army, as well as the citizens of Warsaw, joined the revolt. The defeat of the November Uprising (1830-1831) meant the end of the constitutional period of the Kingdom of Poland. Shortly after, construction of military elements began inside Warsaw Citadel, including prison casemates [6,7].

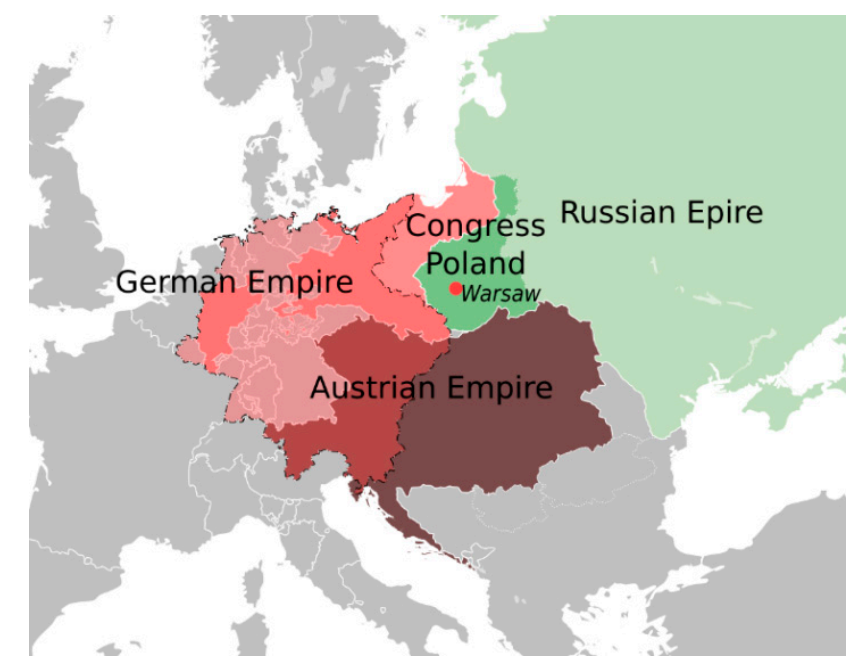

(a)

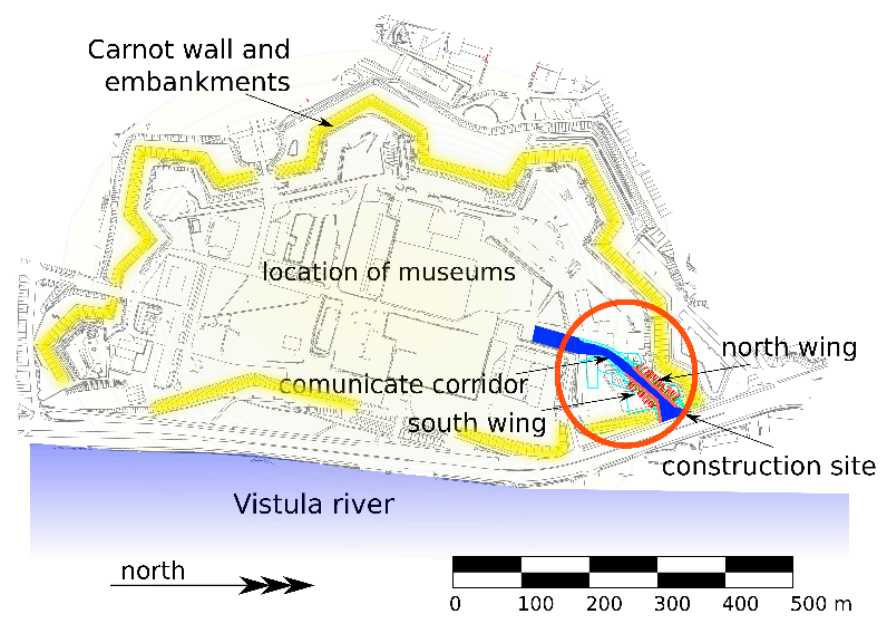

(b)

Figure 1. (a) Geopolitical map of the region in 1815-1914; (b) plan of the fortress with survey area. 
The art of fortification has always found expression in specific works as defensive architecture. The appearance of fortifications was extremely important, starting from the overwhelming dimensions of the buildings to the imposing perfection of the unity, in addition to the usefulness and beauty of the geometrical forms. Parts of fortifications like embankments, walls, towers, caponiers, and the regular net of elements provided ideas for contemporary trend designers [8]. The development of artillery in terms of the range and energy of explosive charges created the psychological impact of the masonry defense objects, playing a representative role even with a complete loss of military significance. Military buildings were subject to a constant process of adapting to the conditions of warfare and the development of weapons, especially firearms. Hence, the impressive and tall medieval brick buildings became useless. They served as a visible target for enemy artillery, and falling masses of debris and destroyed walls wounded defenders.

The research object, the Warsaw Citadel, was being built just before a breakthrough in the art of war. In the middle of the 19th century, the nature of offensive war changed dramatically. The fortifications started to cover much more space around defended locations than previously. The Warsaw Citadel, as a defensive military object, became obsolete shortly after it was constructed [9]. The pivot point was during siege maneuvers of the Julich Citadel (Germany) in September 1860. New Krupp cannons were tested on fortifications with different wall thicknesses. The results were so sensational that the new artillery system was enough to demolish existing fortifications. In West Europe, and especially in Germany, many walls surrounding cities and old fortifications were demolished on a large scale as a result [10]. The most significant change was the replacement of masonry elements by earthworks. Casemates and passages with military, barrack, and warehouse functions were sunk underground or covered with a protective layer of soil. Earthworks became an affordable and effective defense method. As earthworks are the basic construction element, their technical condition and quality played a key role in the efficacy of the defense. The outline of this idea is demonstrated by the Warsaw Citadel; however, the tall walls were still the main defensive element here, and shooting positions were only covered with tiles, which was extremely dangerous for defenders. This is why the remaining complete fortifications developed throughout the 19th century are now valuable as civil engineering infrastructure heritage. Modernization works during the new arrangement of the space inside the Warsaw Citadel (Figure 1b) were completed to search for methods of estimating the heterogeneity of the substrate structure. The compact construction of the rings around the protected interior was cut by contemporary architects for a new communication network [11]. During the crosscuts, the stability of the trench was ensured by means of temporary anchored walls. The anchors were subjected to national standard tests during construction by means of a creep test. The results of the field work were used to develop a method to describe the heterogeneity of the material. Using geostatistical analysis for the rheological model $[12,13]$, an attempt was made to assess embankment condition. To correctly describe the mechanical properties of the soil and anchor connection, fractional derivatives were used.

For locations of anchors, initially, the soil layer was assumed homogeneous based on geological research. Using results obtained from anchor testing data, we constructed a fractional derivative rheological model that explains the behavior of both the anchor immersed in inhomogeneous anthropogenic material and the phenomena on the contact surface between the subsoil and the surface of the fixed anchor within. This paper presents the history of the Warsaw Citadel, especially the period of its construction related to embezzlement and irregularities mentioned by historians, which raised doubts about the quality of the earthworks. Against the background of the era of rapid mechanization of construction works, the handmade works without modern tools and methods available at that time raise many doubts about the purpose of the construction of the object. Previous authors $[7,14]$ provide an answer about the strictly repressive characteristics of the objects that de-emphasized the quality of fortifications. We examined a draft of military doctrine as well as the events in the Kingdom of Poland during its full dependence on Russia, which allowed us to understand the reasons for the low quality of the earthworks and the considerable heterogeneity of the materials, as well as the enormous cost of the objects being constructed. During the search of the archives, briefly 
summarized in the historical part of this paper, we searched for possible failures of the underground part of the facilities, modernization, and reconstruction. We also searched for traces of the older damage suffered by Warsaw during the wars. Earthwork construction heritage was considered, and the designed ground anchors [15] were mounted temporarily into the substrate. Ongoing projects aimed at converting the Warsaw Citadel into a museum object should preserve the features that are important to cultural heritage and earth science conservation for future generations [11].

\section{The Fortress over the Years}

\subsection{Historical Evidence of the Warsaw Citadel: Origin}

The Warsaw Citadel was established for defensive purposes (Figures 2 and 3), but it was also a symbol of the supremacy and strength of the Empire of Russia. The garrison in Warsaw had to protect the conquered areas and prevent possible revolts by the Polish population $[16,17]$.

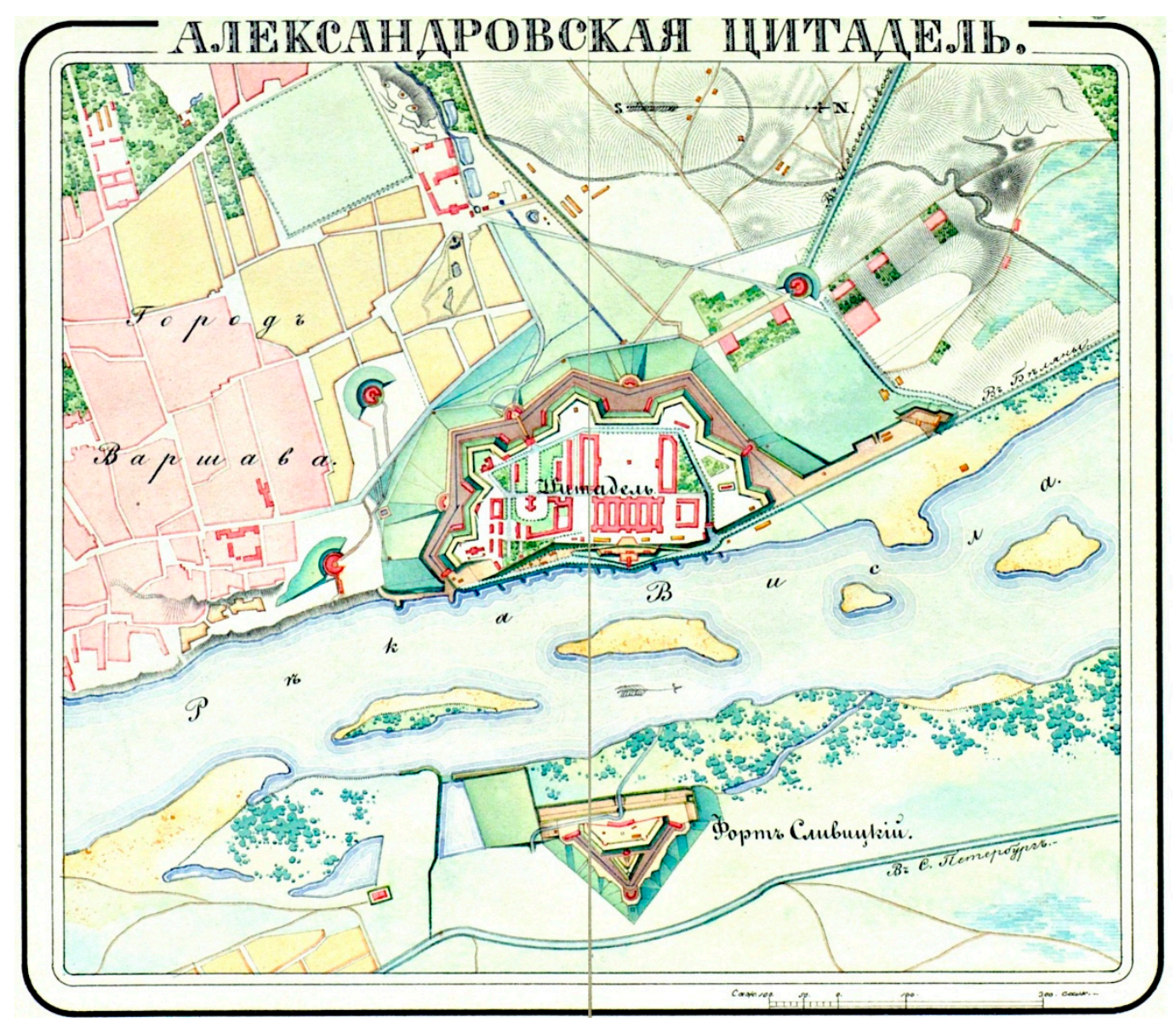

Figure 2. Warsaw Citadel on the pages of the Atlas of Fortresses of the Russian Empire, 1830-1840 [17]. 


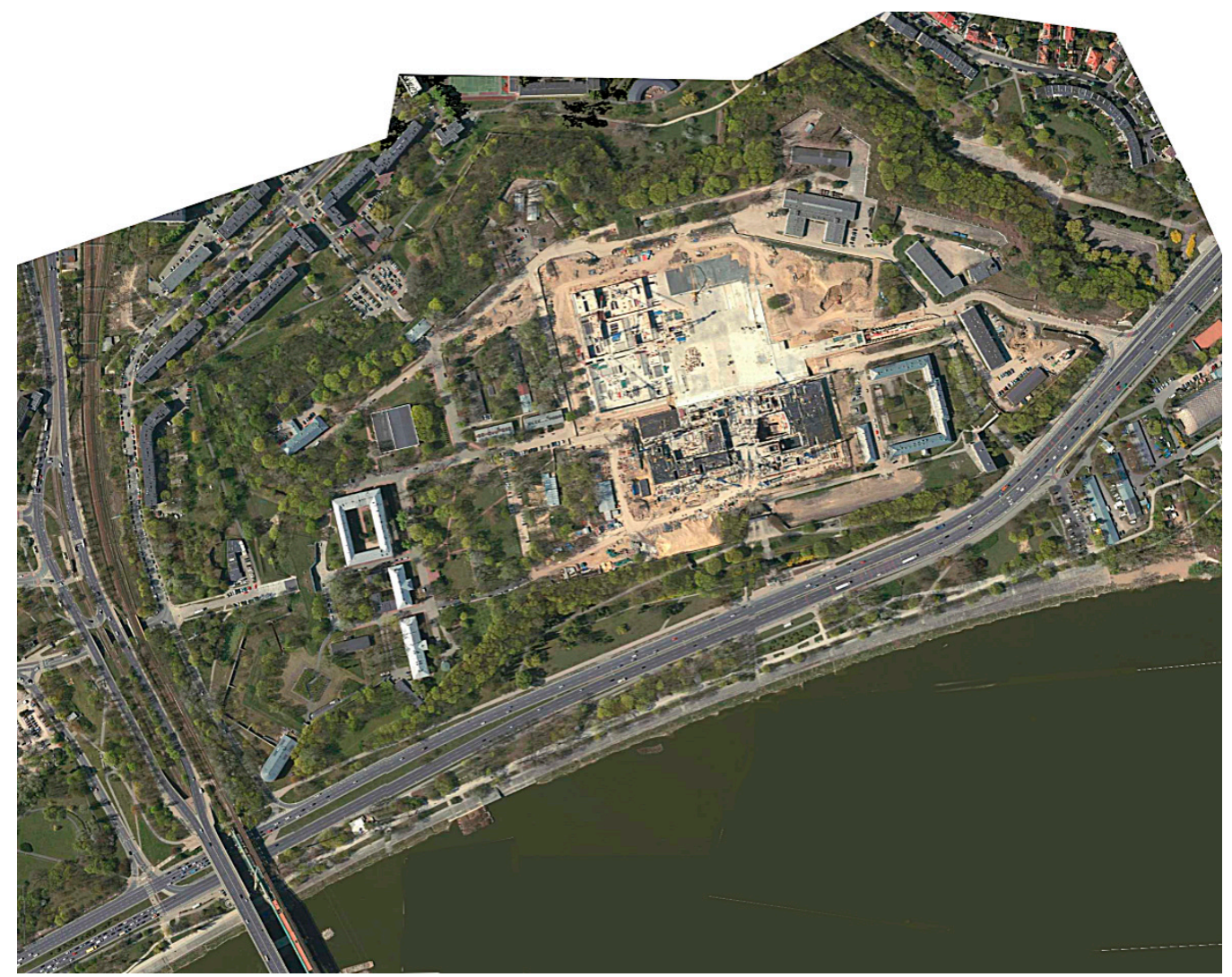

Figure 3. Modern aerial map of the Warsaw Citadel during early-phase modernization, 2018 (source: geoportal.gov.pl, layer with high-density ortophotomap).

After the defeat of the November Uprising [18], all three participants-Russia, Prussia, and Austria-continued the oppression of the Poles. At the end of 1831, serious repressive changes in the political system of the Kingdom of Poland were introduced [19]. As a result, building a fortress in Warsaw became necessary, which could become a point of resistance for the Russian army to guard the capital of the Kingdom of Poland. It had anti-metropolitan characteristics and functions, but due to the military-modified functions and durability of the technical substance, it has survived to the present day. The Warsaw Citadel was established in the district located in the area of the 16th century Fawory manor house and the Piarist Convent from the 17th century. This district was named Żoliborz, resembling the French name joli bord (beautiful coast), because of its charming gardens. Tsar Nicholas I personally decided on 13 March 1832 to build the Warsaw Citadel. This act was to punish revolting citizens of the capital of the conquered country. On 31 May 1832, the cornerstone for the future Warsaw Citadel was laid. The first earthworks were started, shafts were dug, and the moat was excavated. For the next two years, numerous houses in Żoliborz were demolished to make space for the stronghold. On 4 May 1834, after just two years of construction works, the Citadel was solemnly dedicated [6]. A year later, construction works were completed. The tsar was pleasantly surprised because the construction of fortifications lasted only 18 months. All costs related to the construction of fortifications, purchase of land, and their order were transferred to the city of Warsaw [7]. Initially, the workforce was supposed to come from the city's inhabitants, but the designer, General Dehn, objected. He claimed that such difficult work should be carried out by appropriate construction companies. For construction purposes, some army troops and prisoners were used. During the construction works, corruption was rampant; Russian officers and dignitaries dealing with the Citadel suddenly became wealthy people. In total, the Citadel cost about 10 million rubles, which was the equivalent at the time to about $10 \mathrm{Mg}$ of gold.

The shape and functional design of the Warsaw Citadel were based on the common 19th century scheme [20]. The Citadel was created in a polygonal shape with bastions. The general sketch was 
based on a semicircle. The entire fortress was surrounded by an escarpment with a dry moat with counterscarp and an escarpment with Carnot wall (in the polygonal part, the wall was on the top of the embankment). Five bastions were created, with two being half-bastions. On the shoulders of every bastion, there was a single-story cannon outpost.

The solutions used in the Citadel were schematic and corresponded to the knowledge from the beginning of the 19th century. The following were lacking: (1) complete long-range defense, (2) prevention of artillery fire (both flat and high trajectories), (3) ammunition shelters, and (4) defensive barracks.

The ceilings were covered with roof tiles; they had no earthworks or other shelters. Caponiers with a tin roof were unprecedented among others in the era. However, this form was chosen for a certain reason: The Citadel was not intended for defense against a regular army, but only against insurgents deprived of artillery. Therefore, more attention was paid to the possibility of gathering as many soldiers as possible than to increasing its military functions. The fortress, though officially planned as an element of defensive doctrine, finally functioned as a prison as its main role and as barracks for the Russian army. There are indications that the Citadel's objects were designed and constructed in a hurry. This is the reason why we wanted to search for a method to check the homogeneity of the earthworks.

\subsection{The Modern Period (after World War I)}

During the Great War, German troops placed a military radio station in the fortress in 1915, which was taken over by the army of the newly reborn Polish state. From this garrison, the first radio message about the formation of the Polish state was sent on 16 November 1918. The same radio station also played a key role in the war with the Bolsheviks (1919-1920); it served to constantly disturb the enemy's communications and capture encrypted radio telegrams. During the short period of inter-war peace, the fortress served the new Polish army. Three of the seven forts were demolished to recover one of the residential districts of Warsaw for the army officer corps. During World War II, German troops were stationed in the Warsaw Citadel. It was the fortified defense point of the German army, having more of a gendarmerie than military function, as before. The fortress effectively spoiled the plans to liberate the Żoliborz district during the Warsaw Uprising. At the end of the war, Russian troops recovered the Citadel, and this was the only time the Citadel was captured in battle. After the end of the war, the fortress passed into the hands of the Polish army, in which it has been to this day, including serving as the garrison headquarters in Warsaw.

\subsection{Contemporary Development of the Warsaw Citadel}

For museum purposes, according to the concept chosen in the international architectural competition in 2010, the core parts of the historic buildings of the Warsaw Citadel were restored as heritage of military architecture with a newly defined exhibition function. Residents of Warsaw and tourists will have hectares of historic land at their disposal. They will be able to identify the history of this important monument of the Polish nation in the sense that the walls commemorate the turbulent history of Warsaw. The Warsaw Citadel and the Katyń Museum will become important places on the museum map of Poland; the transfer of the Polish Army Museum from the current address will create favorable opportunities for the National Museum in Warsaw at the same time. The Katyń Museum opened on the anniversary of the Katyn execution. The museum commemorates the victims of the People's Commissariat for Internal Affairs (NKVD) murders of 1940. It is the first of three museums that will be built in the Museum Citadel. The most valuable memorabilia in the upcoming Katyn Museum will be property belonging to the murdered Poles, including relics extracted during the exhumation from the burial pits [21]. The decisions regarding the construction of the building of the Museum of Polish History have already been made. After considering all the solutions, it was decided that the new building will be constructed on the premises of the Warsaw Citadel in the museum complex with the existing Museum of the 10th Pavilion, as well as the Katyń Museum and the Polish Army Museum, which are being built. Its construction is just beginning. The Polish History Museum will 
occupy the main location in the complex. The government decided to locate the new headquarters of the Museum of the Polish Army. It will be located on approximately 25 ha of the Warsaw Citadel's area and fragments of its surroundings. The project refers to the historical architectural and urban layout. The building of the museum, together with the cubature buildings (open-air covered exhibition), will be located in the area of the former barracks, which were destroyed during World War II. The restored Gwardia Square, performing representative functions, will be architecturally dominant. The final completion of the move to the premises of the Citadel of the Warsaw Museum of the Polish Army is planned for 2021. In summary, the entire Citadel is going to become a museum complex.

\section{Earthwork Technology and Workmanship}

The design and construction of earthworks require simultaneous application of geodesy (Figure 4), soil mechanics (Figure 5), appropriate equipment, and compliance with workmanship standards. Earthworks were integrated into the system of fortifications that developed along with changes in the art of war. Fortification earthworks led to the development of experience and recommendations in the area of soil mechanics, earthworks, and foundations. These were historical equivalents of modern large infrastructure works in terms of scope and financing from state resources. The period in which the Warsaw Citadel and other fortifications were built is also the period of the whole European industrial revolution. At that time, many crucial modern inventions arose: the steam engine, modern metallurgy, mechanized weaving, and the mass production of paper. The steam excavator was invented and patented in 1836 by William Otis [22]. The first machines were mounted on a railway chassis, to which the boiler, engine, and other drive components were mounted.

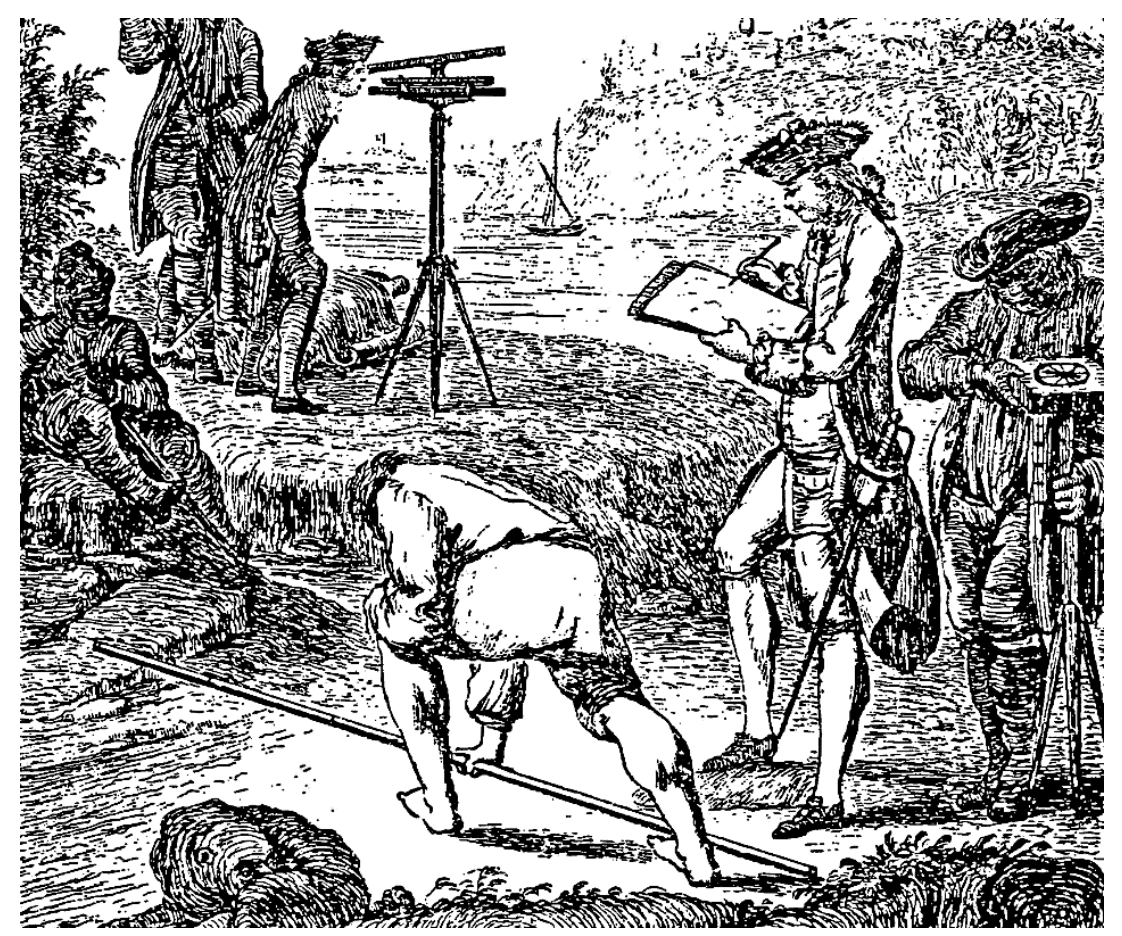

Figure 4. Geodetic measurements [23]. 


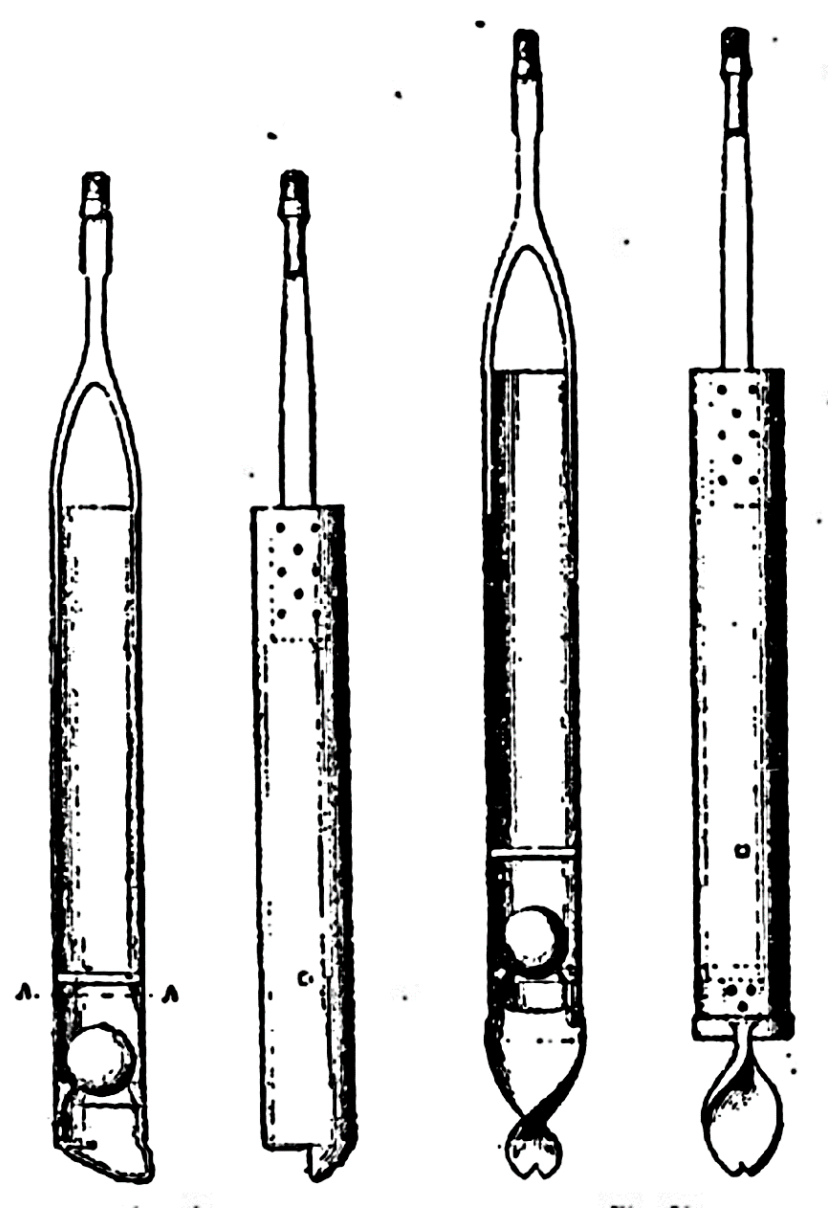

Figure 5. Soil testing equipment from the time of construction [24].

The excavator moved on wide metal wheels driven by a chain transmission (Figure 6). Due to the large mass of the machine, a temporary track was installed to allow the machine to move. This strongly limited its use in earthworks and construction. Steam dredgers became popular in the second half of the 19th century [25]. The first commercial tracked vehicle was the Lombard Steam Log Hauler built in 1901, used originally for logging and timber transport. The first mass-produced machine for agriculture and earthworks was the Fordson farm tractor in 1917. Despite the progress until the 19th century, only basic tools were used for earthworks during the construction of Warsaw Citadel: hand shovels and wheelbarrows, as well as carts and wagons drawn by animals, and sometimes by people as well. Earthworks were dominated by hand tools and cheap mass human labor. A historical source describes thousands of diggers during the construction the Warsaw Citadel. Given restrictions on the transport means for earthworks, local soils close to the locations of fortifications were used. Hundreds of thousands of cubic meters of earth were dug and transported, a large part of which originated from the moat, which was formed using noncompound means, such as wheelbarrows or horse-drawn two-wheeled carts using makeshift roads from wooden dikes. Tools for earthworks in the construction of fortifications in civil engineering [20] did not differ fundamentally from the tools in the later fortification manual [26]. The compaction of earth embankments was made with the help of a heavy oak block with a few wooden handles attached; this was operated by four diggers. The degree of densification of the embankment mainly depended on the reliability of the contractor and supervision. As a result, the embankments of most fortification buildings were often unstable. This resulted in significantly uneven settlement, landslide slopes, and severe deformations. During winter, the rainwater in the moat froze. Winter cycles of freezing and thawing severely influenced the slopes of the escarpment, resulting in landslides and settling. As a result of the random quality of the 
ground and earthworks, the state of earthworks after a short period of time was often characterized by irregular ground elevations, separated in the weakest places by ravines. Summarizing the historical data, the first stage, connected with the visit of the Tsar, was completed in a record-breaking time of 18 months, as compared with the contemporary pace of completely mechanized works. Subsequent stages, after the occurrence of local landslides, were connected with improvement of embankments and the development of the fortification systems.

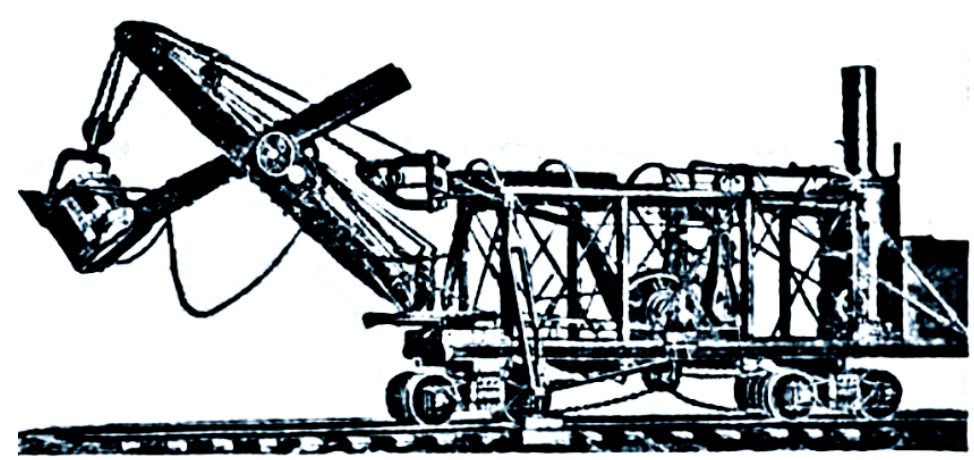

Figure 6. Steam excavator [25].

\subsection{Historical Earthwork Principles}

Earthwork technology in the 19th century did not match the quality of work required today. Audits of the methodical quality control of earthworks and soil parameters in the past were only based on the experience of the responsible engineers.

The classification of soil was strongly related to the labour intensity of its treatment (Table 1).

Table 1. The earthwork value, prepared as a comparison with the percentage of work for simple soil conditions (sandy type) [24].

\begin{tabular}{|c|c|c|c|c|c|c|c|}
\hline \multirow[b]{2}{*}{ Substrate } & \multirow[b]{2}{*}{ Tools } & \multirow{2}{*}{$\begin{array}{l}\text { Labor Intensity } \\
\qquad\left(\mathrm{h} / \mathrm{m}^{2}\right)\end{array}$} & \multicolumn{5}{|c|}{ Earthwork Value $\left(\% / \mathrm{m}^{2}\right)$} \\
\hline & & & Transport & Tools & $\begin{array}{c}\text { Soil } \\
\text { Wagon }\end{array}$ & Supervision & $\begin{array}{l}\text { Final } \\
\text { Value }\end{array}$ \\
\hline $\begin{array}{l}\text { Sand (simply } \\
\text { soil conditions) }\end{array}$ & Spade & $0.5-1.0$ & $48-100$ & 4 & 12 & 8 & 100 \\
\hline Gravel/clay & $\begin{array}{l}\text { Spade, } \\
\text { pick }\end{array}$ & $1.0-1.6$ & $97-161$ & 16 & 20 & 16 & 184 \\
\hline $\begin{array}{l}\text { Gravel/clay } \\
\text { with stone }\end{array}$ & Pick, drill & $1.6-2.4$ & $161-242$ & 24 & 28 & 24 & 277 \\
\hline
\end{tabular}

The basic soil classification into non-cohesive and cohesive soils was general; there were no precise guidelines regarding which soils were suitable for forming embankments or for earthworks in general. Even the much later manual [20] only presented the approximate downgrade of formed slopes, and was the result of poor theoretical knowledge of soil mechanics.

The Citadel was built after the publication of the work that was considered to be the beginning of classical soil mechanics. In 1773, the work of Coulomb [27] was published. Charles Coulomb graduated from the School of Engineering, and, in 1762, he obtained the rank of lieutenant in engineering, designed fortifications, and was put in charge of their construction. In 1772, he resigned from military service and devoted himself to research work. In his manual, Coulomb formulated the basic principles of the limit state and presented its first application to the issue of ground pressure on retaining walls. The Coulomb formula for the shear strength of the soil was, until now, the basic model in soil mechanics. Terzaghi's [28] publication was accepted as the beginning of modern soil mechanics. In this work, Terzaghi systematized the methods of physical and mechanical tests of soil properties and the relationships between the state of soil strain and its shear strength, compressibility, and expansion. 
Along with this, the theory of soil consolidation was also presented. Terzaghi's work initiated a period of rapid and comprehensive development of soil mechanics. Methods of calculating the stability of the earth slopes were published much later [29], and they require the determination of the types and parameters of the soil as well as geotechnical supervision [30]. Calculations of soil pressure for retaining structures and structures embedded in the ground were presented by Rankine [31], who considered the equilibrium of a soil element at any depth in the backfill behind a retaining wall and determined the active earth pressure. As originally proposed, Rankine's theory is only applicable to uniform cohesion-less soil.

At the time of the Citadel's construction, the classical design rules, classification, and necessary laboratory tests of the soil were completely unknown, as listed below. Civil engineering and military architecture also require knowledge in the field of angles and distances as well as that of supervising earthworks. Geodetic instruments at the time of the Citadel's construction were not highly developed [32]. For example, a simple protractor was constructed by Leonard Digges (1515-1559), which was called the "theodolite" at the time. It appeared to be a simple sighting device used to measure horizontal and vertical angles. The Digges device was, for a long time, referred to as the "common theodolet" (ordinary or simple theodolite). The theodolite, a device that enabled triangulation and accurate field measurements, requires a libella (mid-eighteenth century), precise brass elements (the beginning of the 19th century), a precise lathe (after 1830), a measuring screw (1840-1850), and optical glass (1879) [32]. Similarly, geodetic length measurements were recorded using scaled ropes or measuring tapes and did not ensure accuracy, also due to co-existing differing units of measurement. A modern description of construction works technology contains a description of the parameters of the approved materials, necessary equipment, and labor divided among specialists. Historic earthworks of fortifications can be ascribed with certainty to the type of profession-workers with simple equipment-but the quality requirements of geotechnical materials are not mentioned. The description of construction works in sources is reduced to financial and accounting reports.

\subsection{Geotechnical Layout of the Warsaw Citadel}

Sufficient data related to geotechnical conditions in the substrate and the quality of the material become important in the construction and use of massive structures, including fortifications, in particular embankments and in the protection of deep excavations. Warsaw is located in the central part of the country and is the midland geological unit in an area called the Masovian Basin. The basin is filled with Cretaceous-, Tertiary-, and Quaternary-age deposits. The main geomorphological units within the boundaries of Warsaw are the Warsaw Plain (known also from the literature as the Warsaw Upland), the Wolomin Plain, and the Middle Vistula Valley [33]. A significant part of the left bank of Warsaw is located within the Warsaw Plain. This elevated and flat surface lowers gently to the south, west, and north. In the east, it is cut by the Vistula River and forms the high cliff of the Warsaw Slope. In the area of the Warsaw Slope terraces, there are regions with active erosive processes and creeping movements, as well as places with springs, wetland areas, and depressions of suffosion origin. The above factors adversely affect the foundations of buildings and engineering structures, particularly: (1) landslides, (2) the occurrence of an anthropogenic soil layer in the substrate, (3) the occurrence of a layer of low-bearing soils in the substrate, and (4) a shallow level of the underground water table.

As a result of anthropogenic pressure, which especially intensified during the Citadel's construction, the primary terrain was leveled and was additionally raised by building up a layer of anthropogenic embankments (composed of mixed sand, clay, and rubble) with thickness ranging from 0.5 to $5.0 \mathrm{~m}$.

On the right side of the Vistula Valley, the slope is much lower and delimits the Vistula Valley from the Wołomin Plain (Figure 7) [34,35]. In this area lies the highest elevation point of Warsaw (121.12 $\mathrm{m}$ above sea level), located in the easternmost part of the city. The view of the Warsaw Slope with the city skyline is one of the elements that identifies Warsaw. The Slope has a heritage value. The Slope divides the city from south to north. The palaces, which survived the Second World War, are adjacent to the most beautiful parks. The Slope can be defined as the backbone of the city of Warsaw. 
The Warsaw and Wolomin Plains were formed as a result of glacier activities during the Middle Polish Glaciations and the accumulative and erosive activities of river and glacial waters during interglacial periods. Within the Warsaw and Wolomin Plains, the Pleistocene glacial till (sandy clay to clayey sand) predominates. The present Vistula River valley is composed of riverbed and terraces, including a flood terrace (flood plain in the immediate vicinity of the Vistula River bed). The fill terraces are located above the flood terrace (Prague, Bródno, and Skurczyński), dune terraces, and a lacustrine terrace (Radzyminski). River terraces on the left bank of the Vistula river in the area of Śródmieście and Żoliborz form narrow slats adjacent to the Warsaw Slope; in the south (Wilanów) and north (Bielany), they occupy up to $5 \mathrm{~km}$ of the valley's width. A huge part of the right bank of Warsaw is located on the Vistula River terraces. The terraces are alluvial deposits (gravels, sands, silts) and organic sediments (fine-grained soil with organic matter and peats). On the fill and dune terraces, we can find aeolian sands, creating significant areas of sorted sands and dunes. The location of the Warsaw Citadel on the left bank of Warsaw, directly at the river channel within the Warsaw Slope terraces and the Warsaw Plain, is indicated in Figure 7b. Below the embankments can be found Wartanian Glaciation sediments, represented by fluvioglacial and glaciolacustrine sands (fine sands, silty sands, and medium sands), glacial tills (clayey sands, sandy clays with gravels, cobbles, and boulders), and locally lacustrine soils (silt, silty clay, and clay). The total thickness of these sediments ranges from 5.0 to more than $10.0 \mathrm{~m}$. Under the Wartanian Glaciation sediments, consolidated tills of the Odranian Glaciation, fluvioglacial sands, and fluvial sands occur locally. Lithologically, tills consist of clayey sands, sandy/silty clays with gravels, and cobbles with semi-stiff consistency. The above described sediments are all from the Quaternary period according the chronostratigraphy. Older soil substrate from the tertiary and Pliocene periods was drilled at the base of the Slope.

To meet the needs of geotechnical design, the basic geotechnical layers were determined as:

- Layer I, from the top: A layer of humus and anthropogenic embankments up to $5.0 \mathrm{~m}$ thick. The material of this layer is heterogeneous, and contains a significant share of brick rubble [36].

- Layer II: Fluvioglacial sands of the Wartanian Glaciation and medium sands with density index $I_{D}=0.4$ (layer IIa), with density index $I_{D}=0.6$ (layer IIb), and with $I_{D}=0.80$ (layer IIc).

- Layer III: Unconsolidated tills of the Wartanian Glaciation, formed as clayey sands and sandy clays with gravels and cobbles with a hard plastic consistency of plasticity index $I_{L}=0.1-0.2$ (layer IIIa) and semi-stiff consistency $I_{L}<0.0$ (layer IIIlb).

- Layer IV: Glaciolacustrine deposits of the Wartanian Glaciation formed as silts, sandy silts, silty clays, and clays with the hard plastic consistency.

- Layer V: Consolidated cohesive glacial deposits of the Odranian Glaciation consisting of sandy clays and clayey sands with gravel cobbles with a semi-stiff and stiff consistency, with $I_{L} \leq 0.0$.

As mentioned above, the embankments were formed by local soils close to the locations of the fortifications. The substrate classified as native can also be anthropogenic. The exact arrangement of layers can only be revealed during excavations. 


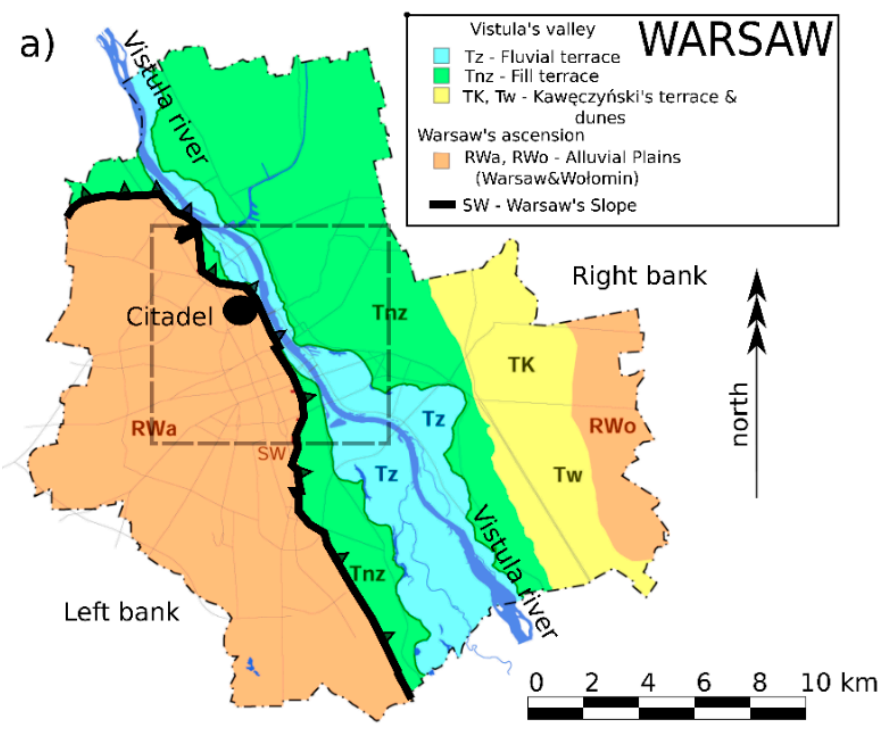

b)

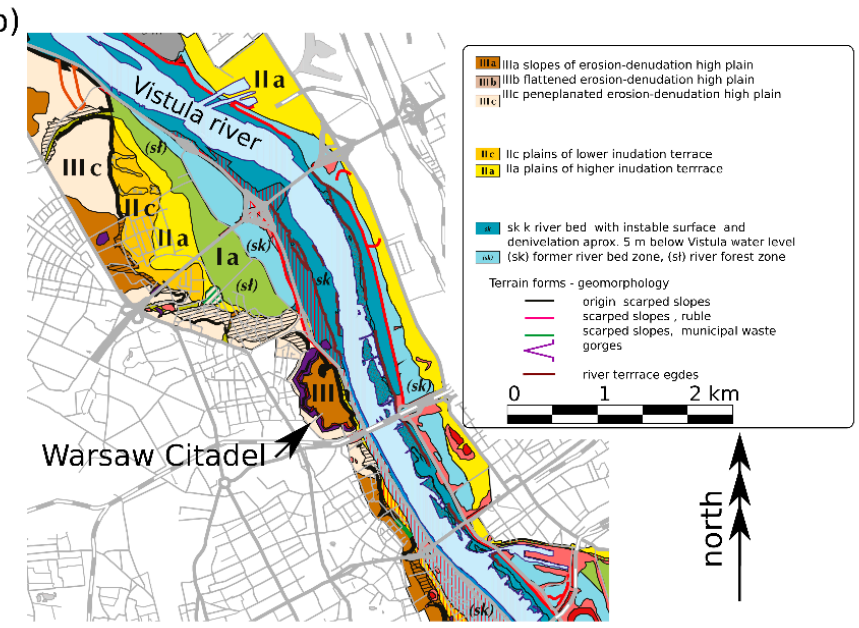

Figure 7. Geomorphology of the Warsaw Valley part of Middle Vistula Valley [10-12]: (a) a general view of Warsaw Valley (base map is on license CC BY-SA 4.0) and (b) magnified area of the Warsaw Citadel.

\section{Description of the Modern (Current) Project}

The first stage of implementation of the entrance to the designed museum object required dismantling of approximately $54 \mathrm{~m}$ of Carnot's wall [11], which was in surprisingly good condition. The excavation under investigation was completed in uncontrolled anthropogenic substrate and in non-cohesive and cohesive subsoil. The task required the identification of a substrate of anthropogenic soils, which required excavation and estimation of geotechnical parameters. With demolitions of the Carnot wall and the soldier-pile wall complete, work progressed on site to complete the excavation (Figure 8a,b).

A soldier-pile wall is a temporary structure with one level of anchoring [37]. The lifetime of the structure is limited, with no predicted change in geotechnical soil parameters during use [38]. Ground anchors mainly carry pulling forces, sometimes slightly transverse, and do not transfer compressive forces. They are mainly applied for the stabilization of excavation trenches and other support structures. The pre-stressed anchors were introduced in one row in intervals of $2.5 \mathrm{~m}$. As the anchoring of the soldier pile wall, DYWIDAG system anchors (DYWIDAG-Systems International GmbH, Plautstraße 80, 04179 Leipzig, Germany) were used with a $6.0 \mathrm{~m}$ long roll length and $420 \mathrm{kN}$ load capacity, lengths of $7.0 \mathrm{~m}$, and a design carrying capacity of $R_{d}=470 \mathrm{kN}$. The Citadel embankments were constructed 
using original local soils close to the locations of the fortifications. The substrate classified as native may also be anthropogenic. The fixed anchors are located in different soil layers with variable physical properties. The locations of the $7.0 \mathrm{~m}$ long and slanting fixed anchors are shown between the marked lines in Figure 9, indicating the position of the fixed anchors in Wartanian Glaciation sediments, represented by fluvioglacial and glaciolacustrine sands (fine sands, silty sands, and medium sands), glacial tills (clayey sands, sandy clays with gravels, cobbles, and boulders), and locally lacustrine soils (silt, silty clay, and clay). The total thickness of these sediments ranges from 5.0 to more than $10.0 \mathrm{~m}$.

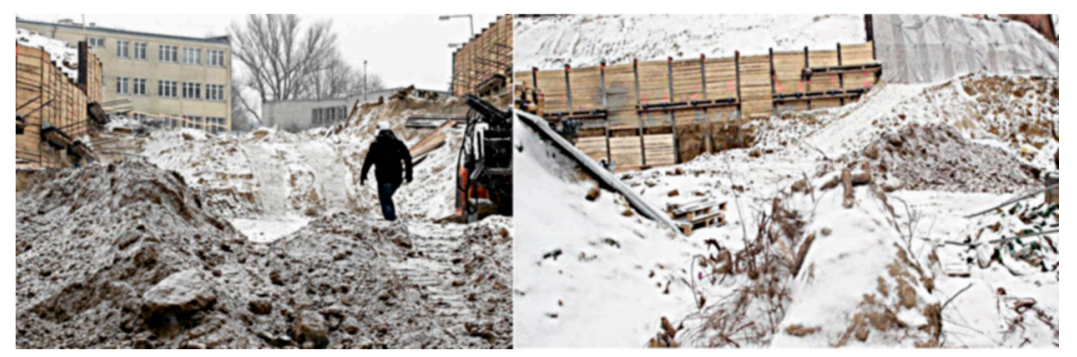

(a)

(b)

Figure 8. (a) View of soldier-pile wall; (b) view of excavation in the Warsaw Slope (author: Wyjadłowski M.).

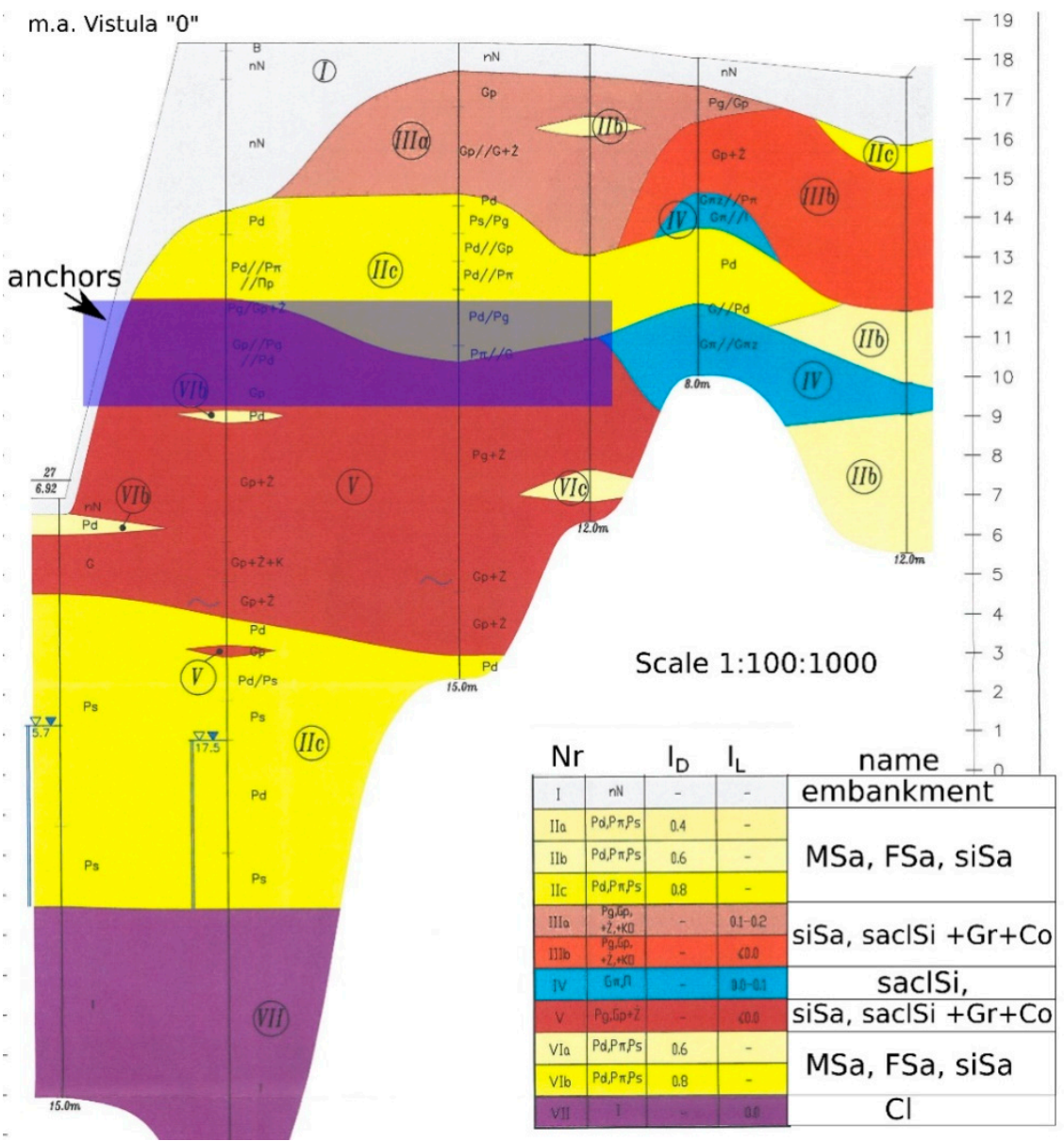

Figure 9. Cross-section along the excavation region (courtesy of Geoteko [36]).

The bearing capacity of the anchors was predicted and designed as a deterministic value based on an empirical formulation; however, due to the random nature of the subsoil, the final verification was 
conducted using creep tests after a static pull-out load test $[39,40]$. The locations of the tested anchors and cross-sections through the excavation are shown in Figure 10.

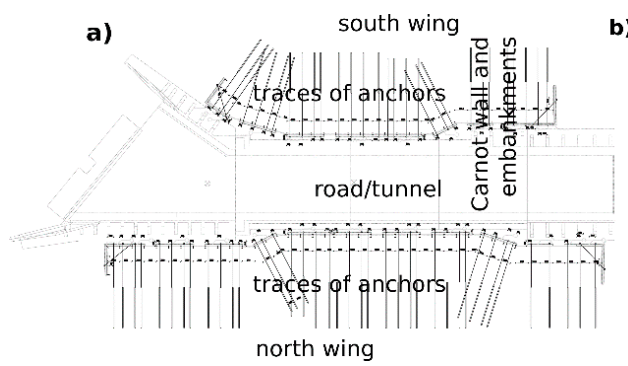

b)

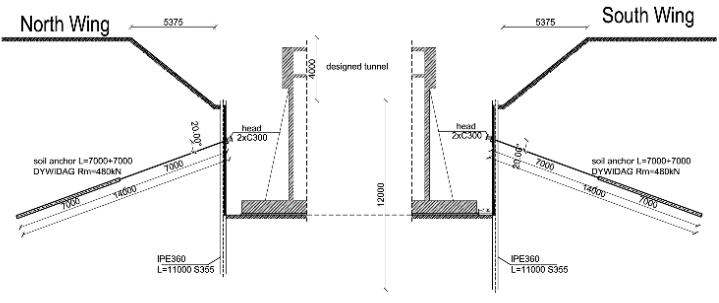

Figure 10. The excavation design: (a) plan and (b) cross-section.

\section{Anchor Design and Testing}

The standard [41] provides the general definition of an anchor as a structure capable of carrying tensile loads through a free length of a tendon onto a support layer. The injection anchor is specified as an anchor with a bolt solidified by injection of resin, cement grout, or other material transferring the tensile force to the ground. Schemes for anchor construction and designations of the structural elements are shown in Figure 11.

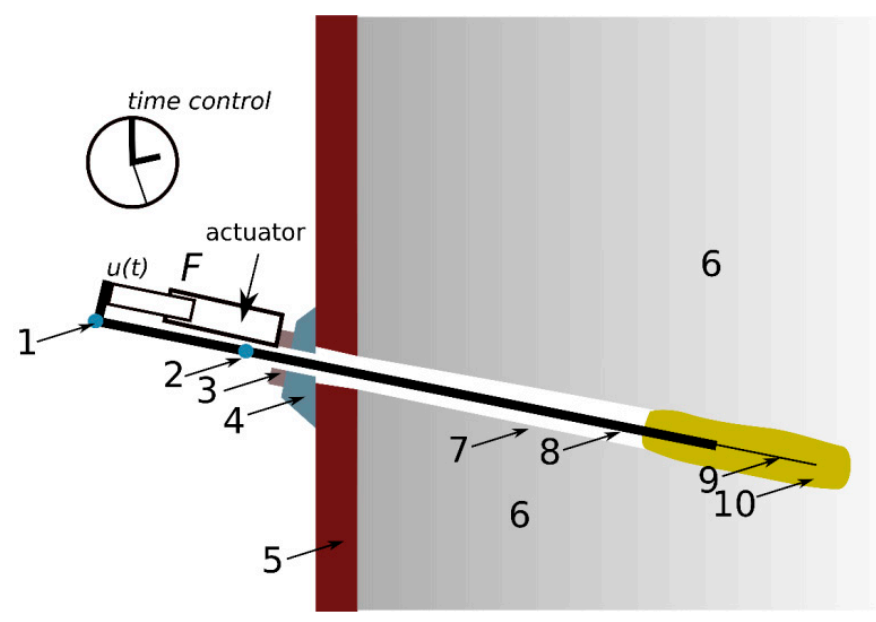

Figure 11. Anchor diagram and description of its elements.

The main document for the testing procedure is the EN 1537 standard [41]. The EN 1997-1 standard [42] presents a complete range of design calculations and implementation procedures for bound ultimate and serviceability limit states. It only concerns the design and testing of anchors with free length. Every anchor made must be tested. Acceptance tests should show that the anchor carries the test load, the free length of the tendon is within the specified limits, and the creep stabilizes during the test. The displacement of the anchor head is measured under constant load in specified conditions and periods of time.

The three applicable test methods are prescribed as acceptance tests [43].

In the case under consideration, we used Test Method 3. The anchor is loaded in incremental steps from a datum load to a maximum load (here, the design bearing capacity of the anchor, $R_{d}$ ). The incremental steps were: $10 \%, 30 \%, 50 \%, 80 \%$, and $100 \%$ of design capacity $R_{d}$. The displacement of the anchorage points was measured under maintained load at each loading step. Creep measurements were recorded between 3 and 15 min of maintained maximum load. For temporary anchors, the maximum creep displacement $s$ at maximum load should be:

$$
s<1.2 \log (T / U)[\mathrm{mm}]
$$


where $T$ is time of experiment $[s]$ and $U$ is unity of time [s].

For the tested anchors, the upper limit was $0.84 \mathrm{~mm}$. This condition was met for all tested anchors. Creep speed tests were also carried out. The maximum creep speed $k_{s}$ during compression should not reach $0.8 \mathrm{~mm}$. $k_{s}$ is determined by:

$$
k_{s}=\frac{\left(S_{2}-S_{1}\right)}{\log \left(\frac{t_{2}}{t_{1}}\right)}
$$

where $S_{2}$ and $S_{1}$ are creep displacement at times $t_{2}$, and $t_{1}$, respectively. Based on the results of maximum creep displacement and creep speed, we determined whether the designed anchor parameters meet the conditions for acceptance and release for use. For further considerations, the results of maximum creep displacements were adopted.

\section{Research Methods}

\subsection{Fractional Integrals and Derivatives}

We conducted standard tests of the anchors placed in the historical embankments of the Warsaw Citadel. The tests were prepared in a fixed load regime applied to the anchor heads using a hydraulic actuator (Figure 11). The test was conducted using the Test Method 3 [43] by increasing the load value in subsequent stages of the experiment with a period of $15 \mathrm{~min}$. The change in head displacement creep was observed. At the initial stage of the experiment, for small deformations, the soil connection with the anchor behaved as an elastic material, as predicted. As the head load approached $R_{d}$, an increase in deformation velocity was observed. At this stage of the experiment, clear rheological effects were observed $[44,45]$. We determined the viscoelastic properties of the connection between the anchors and the ground. The Blair body model was applied, as it is useful and accepted in many mechanical applications for describing mechanical features. The model has already been widely used in physics [46-49] and for rheological bodies [50-52]. A brief introduction with examples of the fractional derivative has been reported in many soil mechanics studies [53-55].

The classic approach to modeling rheological phenomena involves using a combination of basic types of elements: a perfectly elastic body (Hook's law) where the relationship between strain $\varepsilon$ and stress $\sigma$ shows linear dependence:

$$
\sigma(t)=E \varepsilon(t)
$$

A Newtonian liquid with linear dependence between the first time derivative of $\varepsilon(t)$ strains and stress is calculated as:

$$
\sigma(t)=\eta d \varepsilon(t)
$$

where $E$ and $\eta$ are material constants. If the $R_{d}$ value is exceeded by loading, a plastic element is also used.

The tested connection was characterized by both elastic and viscosity features. The combination of these features can be modeled using basic element systems, e.g., the commonly used Maxwell's fluid, Voight's body, standard model, and more complex sets. A number of variants described in the literature were created [56,57]. The proposed model involves an element combining both elasticity and viscosity relationships, which is described as the relationship with the strain derivative fractional value. The introduced concept of the fractional derivative allowed us to describe the mixture of both these features in the basic element as:

$$
\sigma(t)=X_{\alpha}{ }^{C} D^{\alpha} \varepsilon(t)
$$

where $X_{\alpha}$ is the constant coefficient responsible for the dimensional relationship between the material constant $X$ and the order of the derivative $\alpha$; ${ }^{C} D^{\alpha}$ is the Caputo differintegral of function $\varepsilon(t)$, which is 
described in Appendix $\mathrm{A}$; and $\alpha$ is the degree of derivation as a real number within $[0,1)$. Equation (5) produces a pure elastic body (3) when $\alpha=0$ :

$$
\sigma(t)=X_{\alpha}{ }^{C} D^{0} \varepsilon(t)
$$

where $\lim _{\alpha \rightarrow 0} X_{\alpha}=E$, and produces an Newtonian liquid (4) when $\alpha=1$ :

$$
\sigma(t)=X_{\alpha}{ }^{C} D^{1} \varepsilon(t)
$$

where $\lim _{\alpha \rightarrow 1} X_{\alpha}=\eta$. For $\alpha \in\left(0, \frac{1}{2}\right)$, the body has the advantage of elastic properties. For the range $\alpha \in\left(\frac{1}{2}, 1\right)$, viscosity predominates. Hence, the relaxation module for the single time step based on the spring-pot body model has the form

$$
G(t)=\frac{E}{\Gamma(1-\alpha)}\left(\frac{t}{\tau}\right)^{-\alpha}
$$

where $\Gamma$ is the extension of the factorial function to complex numbers (Appendix B), $\tau=\frac{\eta}{E}$, and the creep module is its reverse [58], which is defined as follows:

$$
J(t)=G(t)^{-1}
$$

The value of the power exponent $\alpha$ describes the physical dependence best characterizing the phenomena occurring in the embankment anchor system. We found that these rheological exploratory tools can provide a proper overview of the quantitative and qualitative valuation of the unique features of past military earthworks.

The creep function parameters of experimental data were adjusted by determining the mechanical parameters $E$ and $\eta$ as well as the fractional derivative value $\alpha$ using the least square method (LSM).

\subsection{Spatial Semivariogram Models of Mechanical Parameters}

To fit the theoretical semivariograms to empirical data from 3D surface models, geostatistical methods were used. Semivariograms measure the spatial autocorrelation of acquired sample points. The calculated parameter, i.e., the $E$ value, was used to build an empirical semivariogram with the LSM and the Gauss-Newton algorithm as a nonlinear fitting method. The general form of the semivariograms, according to Equation (10), was used [59], where, for each $h$, half of the mean value of the squared difference $(z(d)-z(d+h))$ is defined as semivariance with a squared length unit:

$$
\gamma(h)=\frac{1}{2 N} \sum_{i=1}^{N}(E(d)-E(d+h))^{2} \forall\{d, d+h\} \in P
$$

where $E(d)$ is the tested anchor location $d, h$ is the lag distance that separates the two analyzed locations along wings of excavation, and $N$ is the number of tested pairs $\{d, d+h\}$ from space $\boldsymbol{P}$, which is all points at the wings with anchors.

For any two locations within a small distance on a surface, a small value of $(z(d)-z(d+h))^{2}$ is expected. With increasing lag distance $h$ between points, the similarity of the measures decreased. This natural behavior can be described by various theoretical relationships, as presented in Table 2 . The nugget model was used for discontinuous characteristics or areas of limited local extent. Spherical, exponential, Gaussian, and linear-plateau models are important among the commonly used semivariograms in engineering applications. 
Table 2. Basic semivariogram models.

\begin{tabular}{cc}
\hline Model Name & Semivariogram \\
\hline nugget & $\gamma(h)=\left\{\begin{array}{l}0 \Rightarrow h=0 \\
s \Rightarrow h>0\end{array}\right.$ \\
\hline linear with sill & $\gamma(h)=\left\{\begin{array}{c}\frac{s h}{r} \Rightarrow h \leq r \\
s \Rightarrow h>r\end{array}\right.$ \\
\hline spherical & $\gamma(h)=\left\{\begin{array}{c}s\left[1.5 \frac{h}{r}-\kappa\left(\frac{h}{r}\right)^{3}\right] \Rightarrow h \leq r \\
s \Rightarrow h>r\end{array}\right.$ \\
\hline
\end{tabular}

Note: $r$, range (L), is a typically constant value limiting the zone of mutual correlation of points in the model; $s$, sill, is the model constant $\left(\mathrm{L}^{2}\right) ; h$, lag distance, is a variable in the model function $(\mathrm{L}) ; \kappa$, a model constant, is typically 0.5 .

When a pair of points appears in an interval, the lag distance between them increases linearly. This concept introduces a statistical measure of $E$ variability based on a distance between points, which is different from subjective deterministic measures. Some specific features of semivariograms are commonly used to describe natural observations:

- The distance where the model first flattens is known as the range $r$ [L].

- Point or sample locations separated by a distance smaller than the range $r$ are spatially autocorrelated, whereas locations farther apart than the range $r$ are not.

- The value attained by the semivariogram model for the range $r$ is called the sill $s\left[\mathrm{~L}^{2}\right]$. The partial sill is the sill minus the nugget $\left[\mathrm{L}^{2}\right]$.

- Theoretically, at zero separation distance $(\mathrm{lag}=0[\mathrm{~L}])$, the semivariogram value is $0\left[\mathrm{~L}^{2}\right]$. However, at an infinitesimally small separation distance, the semivariogram often exhibits a nugget $\left[\mathrm{L}^{2}\right]$ effect, which is some value greater than 0 . The nugget effect can be attributed to measurement error, spatial sources of variation at distances smaller than the sampling interval, or both. Natural phenomena can vary spatially over a range of scales. Variation at small scales smaller than the sampling distance will appear as part of the nugget effect.

The selection of a theoretical model and its fitting procedure are crucial to producing satisfactory prediction and interpretation. The maximum likelihood or least square regression can be used to fit the experimental semivariance. A small and comparable sum of the deviations indicates comparable performance of the models. Therefore, the selection of the semivariogram model is a prerequisite for better performance. It is possible to have several models to choose from, so the selection of a satisfactory model requires the balancing of goodness of fit.

\section{Results}

The concept presented in Equation (8) allowed for a very close match with the displacement results obtained using the standard procedure. The results of the fitting are shown in Figure 12 for test numbers 1-20. A similarly good-quality fitting was obtained for the remaining anchors.

Figures 13-15 show the values of model parameters in two columns. Figure 13a presents histograms, where the values are the frequencies of occurrences, and Figure $13 \mathrm{~b}$ presents matched parameters over the length of the wing of the retaining wall.

The results do not indicate trends in the variability of features. Significant scattering beyond the value of a single standard deviation from the mean was noticed. The heterogeneity of the substrate layer material with anchoring was expected.

The presented model for parameters $\eta$ and $E$ has high correlation values $(>0.8)$. The complete correlation matrix is presented in Table 3, and Figure 16 shows the relationships between the two parameters of the model with the matching linear relationship. 


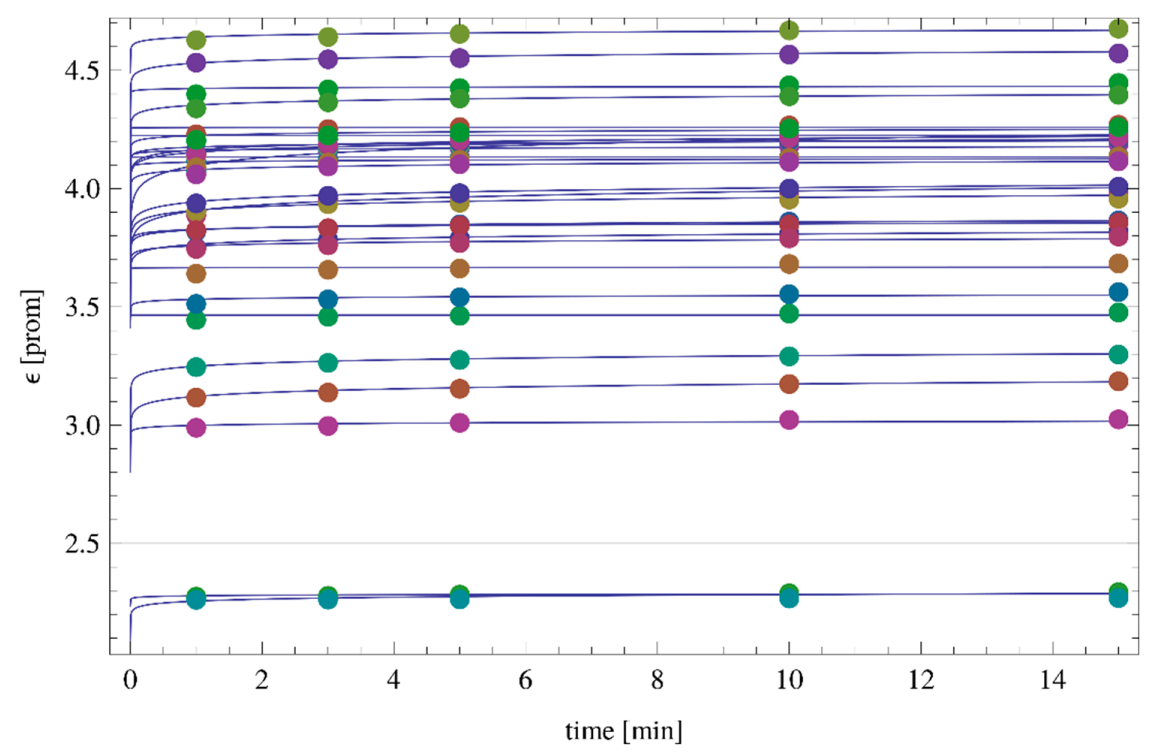

Figure 12. Results of the fitting for the tests of $\varepsilon$ vs. time for anchor numbers 1-20. Each test is represented by a filled circle.

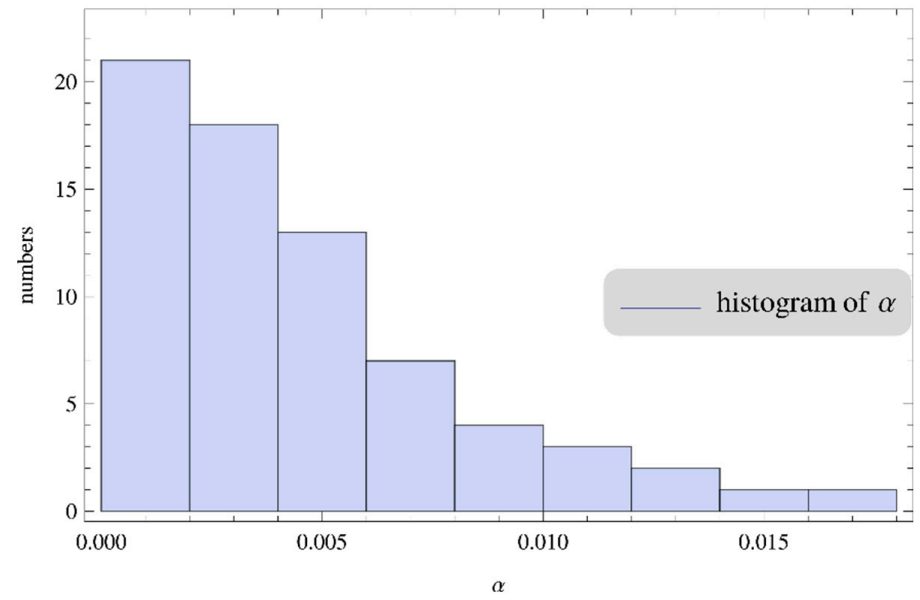

(a)

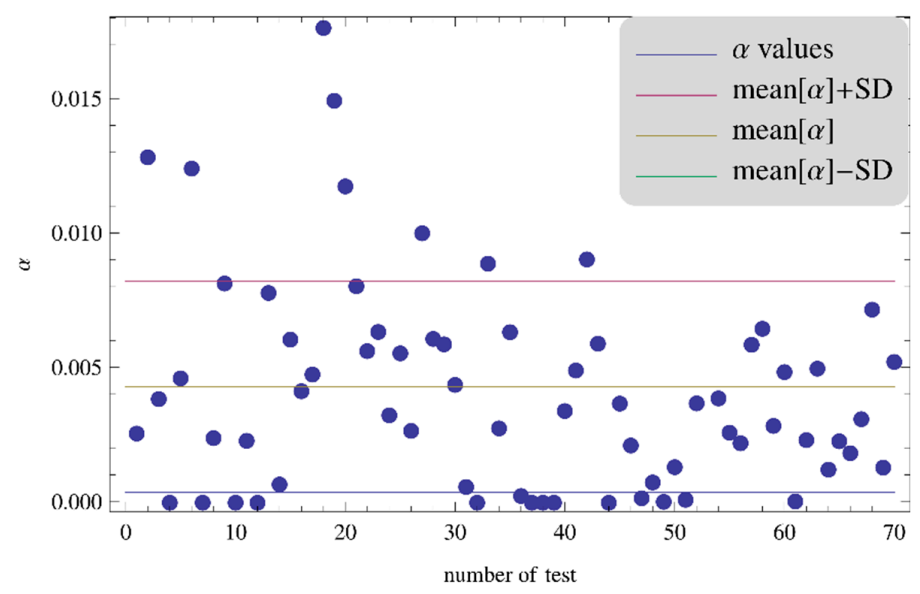

(b)

Figure 13. Graphical presentation of the $\alpha$ value: (a) histogram and (b) all test results in comparison to mean value. 


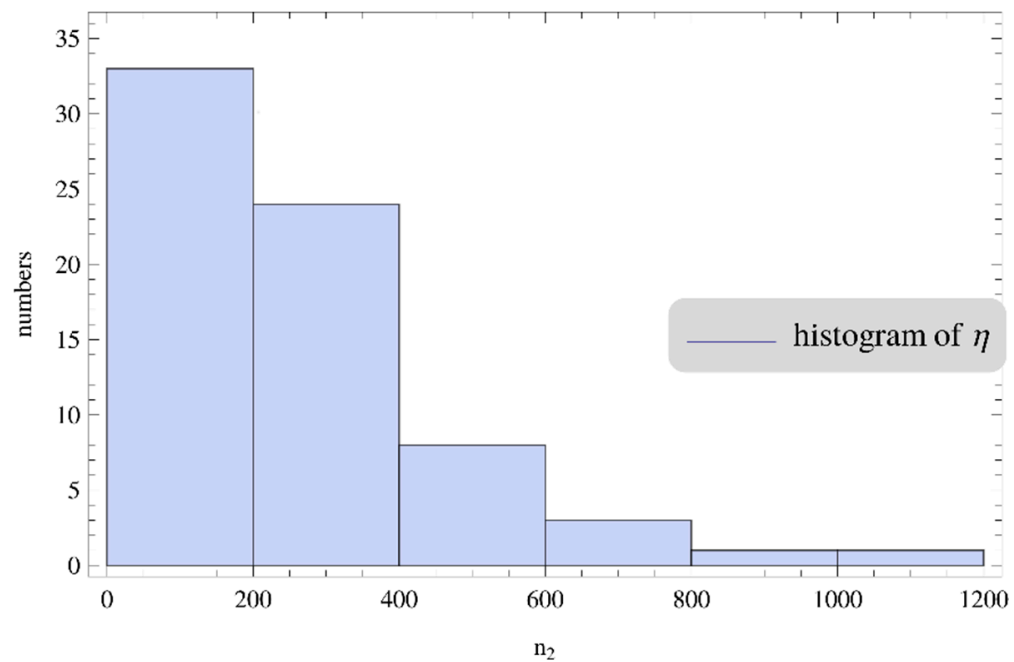

(a)

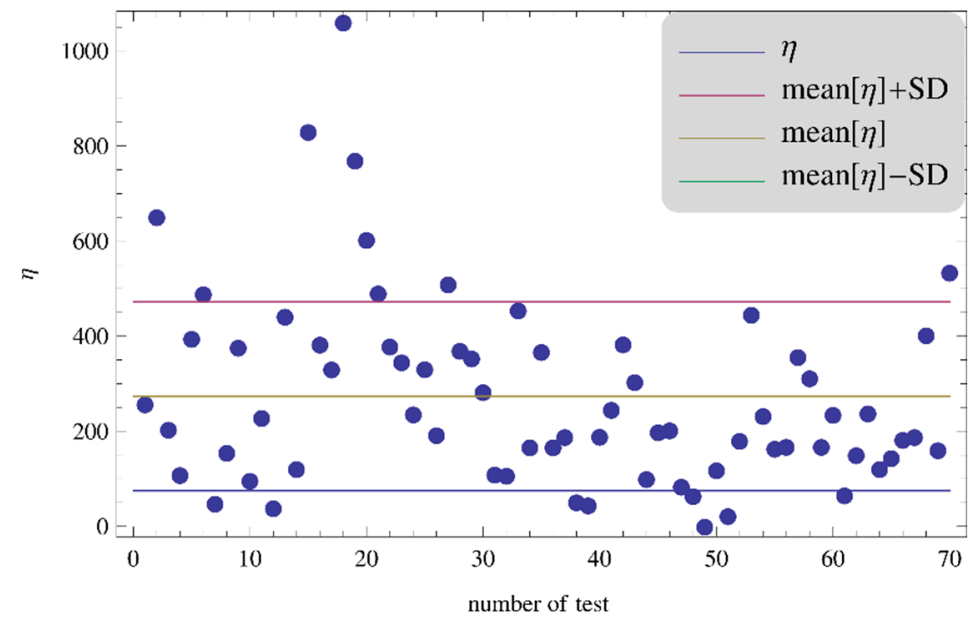

(b)

Figure 14. Graphical presentation of the $E$ value: (a) histogram and (b) all test results in comparison to mean value.

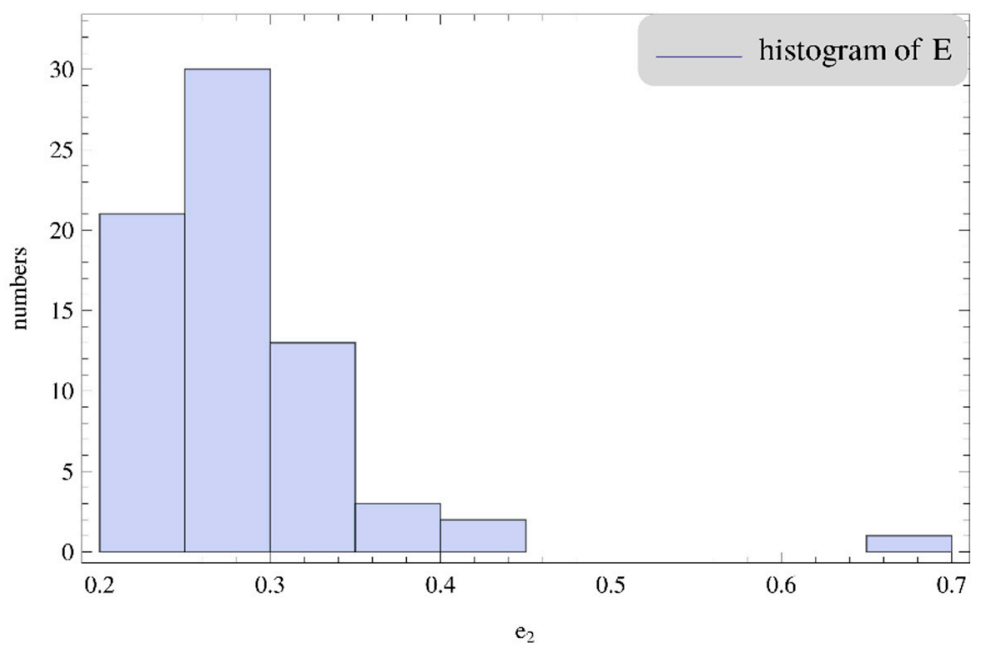

(a)

Figure 15. Cont. 


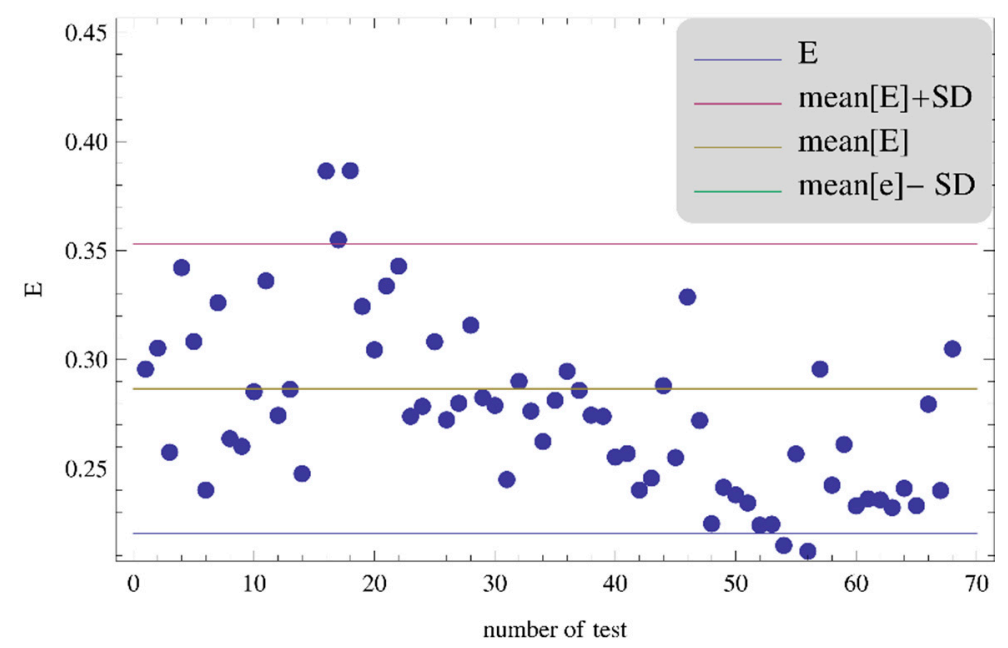

(b)

Figure 15. Graphical presentation of the $\eta$ value: (a) histogram and (b) all test results in comparison to mean value.

Table 3. Correlations between variables for (a) the whole data set, (b) the south wing, and (c) the north wing.

\begin{tabular}{cccc}
\hline Whole Data Set & $E$ & $\eta$ & $\alpha$ \\
\hline$E$ & 1.0000 & 0.5194 & 0.1698 \\
$\eta$ & 0.5194 & 1.0000 & 0.9062 \\
$\alpha$ & 0.1698 & 0.9062 & 1.0000 \\
\hline South Wing & $E$ & $\eta$ & $\alpha$ \\
\hline$E$ & 1.0000 & 0.5064 & 0.1314 \\
$\eta$ & 0.50649 & 1.0000 & 0.9065 \\
$\alpha$ & 0.13147 & 0.9065 & 1.0000 \\
\hline North Wing & $E$ & $\eta$ & $\alpha$ \\
\hline$E$ & 1.0000 & 0.2904 & -0.07858 \\
$\eta$ & 0.2904 & 1.0000 & 0.8720 \\
$\alpha$ & -0.07858 & 0.8720 & 1.0000 \\
\hline
\end{tabular}
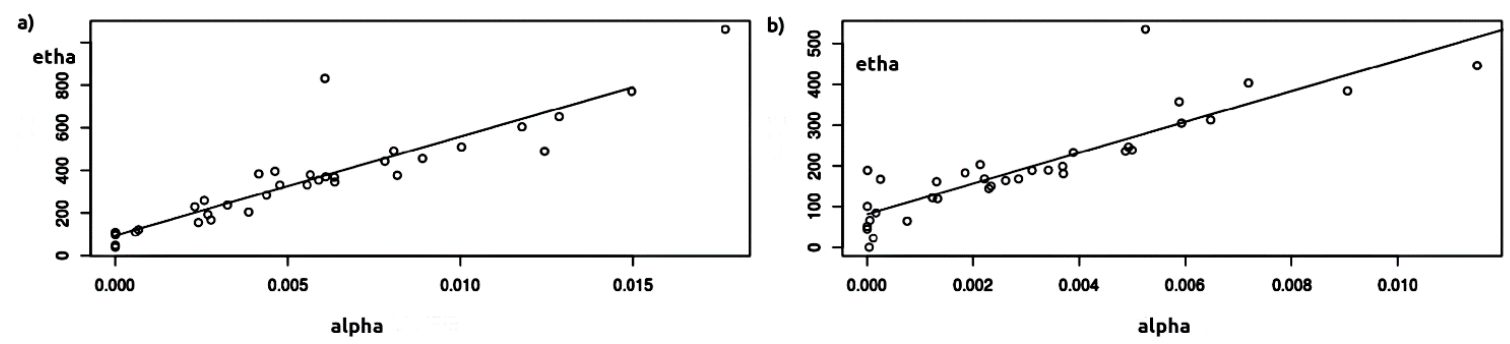

Figure 16. Relationships between $\alpha$ and $E$ in the (a) southern and (b) northern wings.

The linear relationship between these values is:

$$
\eta(\alpha)=C_{1}+C_{2} \alpha
$$


For the south wing, $C_{1}=95.15818$ and $C_{2}=46,334$; in the north wing, $C_{1}=81.67700$ and $C_{2}=37,733$. Hence, the relaxation module of pulled anchors has a spring-pot body for the single time step based on the presented model in the form of:

$$
G(t)=\frac{E}{\Gamma(1-\alpha)}\left(\frac{E t}{C_{1}+C_{2} \alpha}\right)^{-\alpha}
$$

Table 4 presents a set of results for the parameter $E$ : mean, median, and standard deviation per wing and for all results. The modulus of the elasticity $E$ values was in the significant range in the fractional derivative model.

Table 4. Values of the fitting parameters for the whole data set, south wing, and north wing.

\begin{tabular}{cccc}
\hline Parameter & Whole Data & South Wing & North Wing \\
\hline Mean $E$ & 0.2865 & 0.3086 & 0.2644 \\
\hline Median $E$ & 0.2750 & 0.2869 & 0.2461 \\
\hline SD $E$ & 0.06642 & 0.07387 & 0.04991 \\
\hline
\end{tabular}

The direct results of the creep test showed that the substrate material is heterogeneous. Using geostatistical analysis, we extracted new spatial compounds of the examined parameters. Empirical and theoretical semi-variograms of the $E$ value for both investigated embankment wings are presented in Figure 17. The fittings, apart from the heterogeneity scale described by parameter $s$ (sill), provided information that was helpful for the analysis of the quality of ground work with an $r$ (range) value of variable significance. For the analyzed wings, these values differed significantly: 22.1 and 12.1 $\mathrm{m}$ for the north and south wings, respectively. The possibility of matching theoretical models completely contradicted the random distribution of soil features, which is a phenomenon expected in anthropogenic soils.

a) $E^{2}$

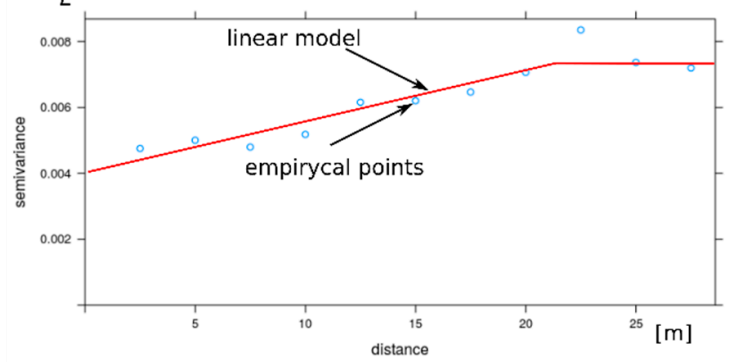

b)

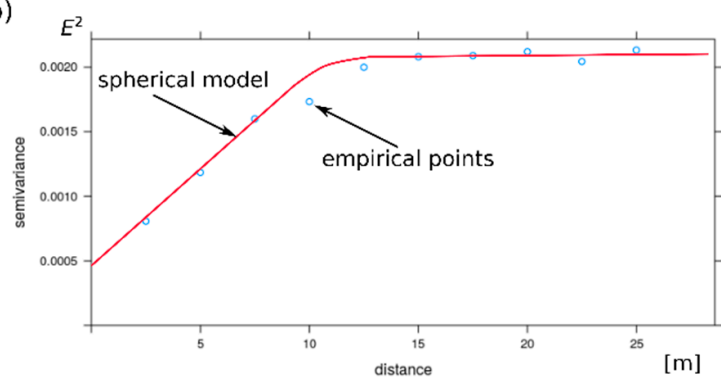

Figure 17. Semivariograms: (a) $E$ for the south wing, with the linear theoretical model fit: $s=0.0071 E^{2}$ and $r=22.10 \mathrm{~m}$; (b) $E$ for the north wing, with the spherical theoretical model fit: $s=0.0021 E^{2}$ and $r=$ $12.1 \mathrm{~m}$.

\section{Conclusions}

In this study, we examined the earthworks and military engineering methods and technologies in the latter period before the industrial revolution in the Russian Empire. The irregularities from the time of construction, as described by historians, were a source of doubt about the quality of the earthworks. The hierarchical investment system, featuring corruption and a lack of supervision over work quality, was typical for the Kingdom of Poland under the tsar's seized power. Original earthworks technology is poorly understood, but the quality and homogeneity of the anthropogenic substrate provided traces of information. The method used for constructing embankments has long-term impacts, including on the success of modernization projects. 
The research object, the Warsaw Citadel, provides a resource for studying past physical, political, and social environments, as well as then-current fortification trends. Military heritage conservation protects significant engineering achievements and can be instrumental in their renewal. In the middle of ongoing heritage renewal projects aimed at converting the Citadel into a contemporary museum center, in this study, acceptance tests of ground anchors were used as a tool to examine the heterogeneity of the fortifications' earthworks. The support elements for the modern retaining wall all passed the tests. In the presented procedure, limitations with respect to the availability of geotechnical surveys were overcome. The geological and geotechnical layouts of the site and historical earthworks, from when technology was based on hand work and lacked geotechnical theory, resulted in poor-quality and unreliable embankments and foundations.

Historical sources mention a number of faults removed during the embankment operation phase. Some of them resulted from a lack of geotechnical recognition and others from incorrectly performed earthworks. We attempted to verify these faults after hundreds of years. Anchor tests allowed us to assess the randomness of substrate, which resulted from the geological layout and the complex stress history. The results of the load tests indicated the composite mechanical properties of the anchors and soil. The material of the anchor elements was standardized and its variability was assumed to be negligible. An indirect method was used for determining the parameters of the rheological model of the substrate; it was treated as an element with rheological nature. The soil-anchor interaction was described using the fractional derivative rheological model parameters $E, \eta$, and $\alpha$. The parameters of the rheological model were obtained using fitting methods with the field test results. Analysis of the distribution of these values in the profile did not allow us to draw direct conclusions due to the strong local heterogeneity of the soil. The applied geostatistical approach indicated the existence of spatial relationships amongst the model parameters. Dike construction was not subject to the current technological regime, and its quality was strongly influenced by the type of built-in materials, demonstrated by high values of standard deviations for each model parameter. The spatial variability of parameters $E, \eta$, and $\alpha$ of the fractional derivative model was presented using theoretical semivariograms fitted to empirical values. The spherical and linear semivariogram models were selected to accomplish the specific objectives of this study. The semivariograms were used to explain the spatial autocorrelation of the tested sample points. Theoretical models produced the range parameters of 22.1 and $12.1 \mathrm{~m}$ for the north and south wing, respectively. The values of the range in the theoretical semivariograms were significantly different between the southern and northern wings. In both cases, we found a certain repetitiveness in the variability of the model parameters. This relationship suggested no randomness in the construction method and the influence of the consolidation processes. We found no spatial dependence between the position of the anchor and the value of the model parameters. However, we detected a correlation between two different types of earthwork methods or teams. The first group operated in an area of about $12.1 \mathrm{~m}$, and the second group covered about twice the area. The values of direct soil compaction, after years of consolidation, are not a reliable indicator of the quality of works in the past. The significant differences in the quality of work for the two identified teams, found after several hundred years, confirmed the historical reports about poor supervision and probable financial scams. These past irregularities are hard to directly determine. However, our findings contribute to the description of the methodology used for governance in a despotic state such as tsarist Russia, where the most important investments from the viewpoint of state security were decided based on poorly defended and differently constructed foundations.

By determining the characteristics of the creep model, the results of the empirical analysis indicated a considerable heterogeneity of the model parameters in the embankments and the Wartanian Glaciation sediments. This may suggest different origins of soil material for embankments, the monitoring of stages of the work, variable compaction quality, and lack of effective work acceptance procedures. Our findings provide a tool for detecting hidden geodiversity patterns within infrastructure areas that lack apparent surface soil variability, as well as for overcoming the limitations of traditional methods used for assessing diversity, by introducing civil engineering outcomes. This study provides 
geotechnicians with additional information for assessing the methodology of the construction of an object. The supplementary characteristic of the method should be emphasized; it must be supplemented through historical query and additional research on direct geotechnical reconnaissance.

Author Contributions: Conceptualization, M.W. and J.K.; Methodology, M.W. and J.K.; Software, J.K. and W.D.; Validation, M.W. and W.D.; Formal Analysis, M.W. and J.K.; Data curation, M.W. and W.D.; Writing-original draft preparation, M.W., J.K. and W.D.; Writing-review and editing, M.W., M.W. and W.D.; Visualization, J.K. and W.D. All authors have read and agreed to the published version of the manuscript.

Funding: This research received no external funding.

Acknowledgments: The authors would like to express their gratitude to Gollwitzer Polska Ltd. for technical support of this study and for making the construction site available for research.

Conflicts of Interest: The authors declare no conflict of interest. The funders had no role in the design of the study; in the collection, analyses, or interpretation of data; in the writing of the manuscript, or in the decision to publish the results.

\section{Appendix A}

Necessary prerequisites for fractional integrals and derivatives analyse is Laplace image of a function derivative:

$$
\mathcal{L}\left\{\frac{d^{n} y(t)}{d t^{n}}, t, s\right\}=s^{n} Y(s)-\sum_{k=1}^{n} s^{n-k} y^{(k-1)}
$$

where $y(t)$ is an original function of one real variable, which is integrable on $[a, T]$, such that the Lebesgue integral converges at least for one complex variable $s ; Y(s)$ is Laplace's image of the original function in space $s$; the real constants $a, T$, and $\alpha$, where $a<T, n_{c}=\max (0,-[-\alpha])$; and $n_{c}$ is the times differentiable on $[a, T)$, except on a set of zero measure when $n_{c}>0$. Then, the Caputo differintegral ${ }^{C} \mathrm{D}$ is defined for $t$ in $[a, T)$ as

$$
{ }^{C} D_{a}^{\alpha} y(t)=\frac{1}{\Gamma\left(n_{c}-\propto\right)} \int_{a}^{t}(t-\tau)^{n_{c}-\alpha-1} y^{\left(n_{c}\right)}(\tau) d \tau
$$

In the case of fractional derivatives (also called differintegral), integration and differentiation are inverse operations:

$$
{ }^{c} D_{a}^{\alpha} y(t)=I_{a}^{n_{c}-\propto}\left[\frac{d^{n_{c}} y(t)}{d t^{n_{c}}}\right] .
$$

Solving the differential equation of the model with the operator method (Laplace transform), it is necessary to determine the fractional derivative transform (with assumption $a=0$ ):

$$
\mathcal{L}\left\{{ }^{C} D_{0}^{\alpha} y(t), t, s\right\}=s^{\alpha} Y(s)-\sum_{k=1}^{n_{c}} s^{\alpha-k} y^{(k-1)}(0)
$$

\section{Appendix B}

The gamma function of $z$ is defined per Lagrange as

$$
\Gamma(z)=\int_{0}^{\infty} x^{z-1} e^{-x} d x
$$

if $\mathcal{R}(z)$ (the real part of $z$ ) is positive.

\section{References}

1. Nowak, T.M. Studies of the History of Military Technology in Poland. Kwart. Hist. Nauk. I Tech. 1980, 4, 721-730. 
2. Fallavollita, F.; Ugolini, A. New Methodologies for the Documentation of Fortified Architecture in the State of Ruins. Int. Arch. Photogramm. Remote Sens. Spat. Inf. Sci. ISPRS Arch. 2017, 42, 411-418. [CrossRef]

3. Gawryluk, D.; Zagroba, M. Protection of Landscape Values of Historical Post Military Objects-Complexes in Spatial, Urban and Architectural Planning of Polish Cities. IOP Conf. Ser. Earth Environ. Sci. 2017, 95, 052020. [CrossRef]

4. Krcho, J. From Military Bakery to Kulturpark: The Problematics of the Former Military Complex in Kosice. Archit. Urban. 2013, 47, 254-265.

5. Niculita, M.; Margarint, M.C. Landslides and Fortified Settlements as Valuable Cultural Geomorphosites and Geoheritage Sites in the Moldavian Plateau, North-Eastern Romania. Geoheritage 2018, 10, 613-634. [CrossRef]

6. Mościcki, J. Warsaw Citadel. Outline of Construction History; Towarzystwo Miłośników Historii w Warszawie: Warszawa, Poland, 1963. (In Polish)

7. Łagowski, S. Cytadela Warszawska 1832-2007, 2nd ed.; Oficyna Wydawnicza AJAKS: Pruszków, Poland, 2009. (In Polish)

8. Kamińska, M.; Skrok, Z. Warsaw-Warsaw Citadel. Port Kaponiera. Inf. Archeol. 1983, 20, 233. (In Polish)

9. Naronowicz-Naroński, J. War Construction; Anusiewicz, M., Ed.; Wydawnictwo Ministerstwa Obrony Narodowej: Warszawa, Poland, 1957. (In Polish)

10. Marten, B.; Meyer, N. Festungsbau. Geometrie-Technologie-Sublimierung; Lukas Verlag: Berlin, Germany, 2012.

11. Construction Project: Complex Polish Army Museum. The Entrance along with the Tunel; WCXA Ltd.: Warszawa, Poland, 2013.

12. Tomanovic, Z.; Miladinovic, B.; Zivaljevic, S. Criteria for Defining the Required Duration of a Creep Test. Can. Geotech. J. 2015, 52, 883-889. [CrossRef]

13. Arindam, D.; Basudha, P.K. Applicability of Burger Model in Predicting the Response of Viscoelastic Soil Beds. In Geo-Florida-2010: Advances in Analysis, Modeling and Design, Geotechnics, 2611-2620; Geotechnical Special Publication: Orlando, FL, USA, 2010.

14. Cabana, W. The Nineteenth-Century Ideas of Polish Roads to Independence. Yearb. Inst. East-Cenral Eur. 2018, 16, 105-127.

15. Sabatini, P.J.; Pass, D.G.; Bachus, R.C. Geotechnical Engineering Circular No. 4-Ground Anchors and Anchored Systems; Departament of Transportation, Federal Highway Administration: Washington, DC, USA, 1999.

16. Taras, Е.А. Анатомия Ненависти. Русско-Польские Конфликты вXVIII-XX Bв(in Russian, Hate Anatomy. Russian-Polish Conflicts in XVIII-XX Th Century.); Harvest: Minsk, Belarus, 2008; ISBN 978-985-16-1774-2.

17. Atlas of Fortressses of the Russian Empire 1830-40. n.d. Available online: http://Science.Totalarch.Com/Book/ 0652.Rar (accessed on 15 March 2020). (In Rusian).

18. Milewicz, P. The Legacy of the French Revolution and the November Uprising in the Kingdom of Poland, 1815-1831. In Historicising the French Revolution; Armenteros, C., Blanning, T., Di Vanna, I., Dodds, D., Eds.; Cambridge Scholars Publishing: Newcastle upon Tyne, UK, 2008; pp. 245-265.

19. Grajewski vel. Zurawski, R. Poland in the Period of Partitions 1975-1914. In Poland-History, Culture and Society. Selected Readings; Bielawska-Batorowicz, E., Rasiński, R., Eds.; Uniwersytet Łódzki: Łódź, Poland, 2015; Available online: http://dspace.uni.lodz.pl/xmlui/bitstream/handle/11089/16589/095_125_grajewski. pdf? sequence $=1 \&$ isAllowed $=y$ (accessed on 15 March 2020).

20. Langins, J. Conserving the Entlightenment: French Military Engineering from Vauban to the Revolution; Massachusets Institute of Technology: Cambridge, MA, USA, 2004.

21. Białkiewicz, J. Katyń Museum in the Warsaw Citadel-Historic Object in the Interpretation of Modern Museum Architecture. J. Herit. Conserv. 2017, 52, 59-73. [CrossRef]

22. Welch, R.; Lamphier, P.A. Technical Innovation in American History: An Encyclo-pedia of Science and Technology, Volume One Colonial America to 1865; ABC-CLIO: Santa Barbara, CA, USA, 2019.

23. Montesson, D. Dupain de Montesson's art of surveying applied to everything to do with war, navigation and civil and military architecture. In fr. L'art de lever les Plans Appliqué à Tout ce qui a Rapport à la Guerre, à la Navigation et à l'architecture Civile et Militaire par Dupain de Montesson; Verkaven, J.J., Ed.; Paris, France, 1804; Available online: https://catalogue.bnf.fr/ark:/12148/cb39315234d (accessed on 15 June 2020).

24. Procédés Généraux de Construction [Texte Imprimé]: Travaux d'art/par A. de Préaudeau; avec la Collaboration de E. Pontzen; C. Béranger: Paris, France, 1901-1903; Available online: https://catalogue.bnf.fr/ark:/12148/ cb31147777q (accessed on 15 June 2020). 
25. Engineering News-Record, A Journal of Civil Engineering and Construction; Mc Graw-Hill Company, Inc.: New York, NY, USA, 1924; pp. 49-51.

26. Biesiekierski, K. Field Fortication; Główna Księgarnia Wojskowa: Warszawa, Poland, 1922. (In Polish)

27. Coulomb, C.A. Essai Sur Une Application Des Règles de Maximis et Minimis à Quelques Problèmes de Statique, Relatifs à l'Architecture; Del'Imprimere Royale: Paris, France, 1776.

28. Terzaghi, K. Erdbaumechanik Auf Bodenphysikalisher Grundlage; Deuticke: Wien, Austria, 1925.

29. Fellenius, W. Erdstatische Berechnungen Mit Reibung Und Kohaesion (Adhaesion); W. Ernst \& Sohn: Berlin, Germany, 1927.

30. Sobala, D.; Rybak, J. Role to Be Played by Independent Geotechnical Supervision in the Foundation for Bridge Construction. IOP Conf. Ser. Mater. Sci. Eng. 2017, 245, 022073. [CrossRef]

31. Rankine, W. On the stability of loose earth. Philos. Trans. R. Soc. Lond. 1857, 147, 9-27.

32. Smith, J.R. Introduction to Geodesy: The History and Concepts of Modern Geodesy; John Wiley\&Sons, Inc.: Hoboken, NJ, USA, 1997.

33. Bogdański, J. Geomorphological Conditions. In The Natural Environment of Warsaw; Wróblewski, A., Biernacki, Z., Kazimierski, J., Eds.; Polskie Wydawnictwo Naukowe: Warszawa, Poland, 1990; pp. 90-97. (In Polish)

34. Biernacki, Z.; Teysseyre-Sierpińska, M.; Pietrusiewicz, W. Map Vistula River Range with Warsaw Slope. Geomorphology; Dom Wydawniczy ELIPSA: Warszawa, Poland, 2000.

35. Pawlak, J.; Teysseyre-Sierpińska, M. Ecophysiographic Survey to Study the Conditions and Directions of Spatial Development In the Capital City of Warsaw; Office of Architecture and Spatial Planning of the Capital City of Warsaw City Hall: Warszawa, Poland, 2006. (In Polish)

36. Geoteko Ltd. Construction of the Complex along with Technical Infrastructure. Geotechnical Foundation Conditions; Geoteko Ltd.: Warszawa, Poland, 2013.

37. Urbański, A. A Simplified computational model for a periodic system of horizontally loaded piles. In Computational Geomechanics, Proceedings of the 3rd International Symposium On Computational Geomechanics, ComGeo III, Krakow, Poland, 21-23 August 2013; Pietruszczak, S., Pande, G.N., Eds.; International Centre for Computational Engineering (IC2E): Rhodes, Greece; Swanesea, UK, 2014; pp. 516-524.

38. Turner, M. Geotechnical Design of Ground Anchors. In ICE Manual of Geotechnical Engineering: Volume II.; Burland, J., Chapman, T., Skinner, H., Brown, M., Eds.; ICE Virtual Library: London, UK, 2012.

39. Štefaňák, J.; Miča, L.; Chalmovský, J.; Leiter, A.; Tichý, P. Full-Scale Testing of Ground Anchors in Neogene Clay. Procedia Eng. 2017, 172, 1129-1136. [CrossRef]

40. Wu, Z.; Yang, S.; Wu, Y.; Hu, X. Analytical Method for Failure of Anchor-Grout-Concrete Anchorage Due to Concrete Cone Failure and Interfacial Debonding. J. Struct. Eng. 2009, 135, 356-365. [CrossRef]

41. EN 1537 European Standard. Execution of Special Geotechnical Work-Ground Anchors; European Committee for Standardization: Brussels, Belgium, 1999.

42. EN 1997-1. Eurocode 7: Geotechnical Design-Part 1: Genaral Rules; European Committee for Standardization: Brussels, Belgium, 2009.

43. EN ISO 22477-5. Geotechnical Investigation and Testing-Testing of Geotechnical Structures Part 5: Testing of Grouted Anchors; European Committee for Standardization: Brussels, Belgium, 2018.

44. Xu, H.; Lu, H.; Qian, Q. Creep Damage Effects of Pulling Grouting Anchor in Soil. Chin. J. Geotech. Eng. 2002, 24, 61-63.

45. Bhat, D.R.; Bhandary, N.P.; Yatabe, Y. Residual-State Creep Behavior of Typical Clayey Soils. Nat. Hazards 2013, 69, 2161-2178. [CrossRef]

46. Oldham, K.B.; Spanier, J. The Fractional Calculus; Academic: USA, New York, 1974.

47. Miller, K.S.; Ross, B. An Introduction to the Fractional Integrals and Derivatives-Theory and Application; Wiley: New York, NY, USA, 1993.

48. Samko, S.G.; Kilbas, A.A.; Marichev, O.I. Fractional Integrals and Derivatives Theory and Applications; Gordon and Breach Science Publishers: New York, NY, USA, 1993.

49. Hilfer, R. Aplication of Fractional Calculus in Physics; Universitaet Mainz \& Universitaet Stuttgart: Mainz, Germany, 2000.

50. Podlubny, I. Fractional Differential Equations; Academic Press: San Diego, CA, USA, 1999.

51. Kilbas, A.; Marichev, O.; Samko, S. Fractional Integrals and Derivatives; Gordon and Breach Science Publishers: Berlin, Germany, 1987. 
52. Di Paola, M.; Zingales, M. Exact mechanical models of fractional hereditary materials. J. Rheol. 2012, 56, 983-1004. [CrossRef]

53. Di Paola, M.; Pirrotta, A.; Valenza, A. Visco-elastic behavior through fractional calculus: An easier method for best fitting experimental results. Mech. Mater. 2011, 43, 799-806. [CrossRef]

54. Di Paola, M.; Pinnola, F.P.; Zingales, M. A discrete mechanical model of fractional hereditary materials. Meccanica 2013, 48, 1573-1586. [CrossRef]

55. Di Paola, M.; Pinnola, F.P.; Zingales, M. Fractional differential equations and related exact mechanical models. Comput. Math. Appl. 2013, 66, 608-620. [CrossRef]

56. Atanackovic, T.M.; Pilipovic, S.; Stankovic, B.; Zorica, D. Fractional Calculus with Applications in Mechanics: Vibrations and Diffusion Processes; Wiley-ISTE: London, UK, 2014.

57. Diethelm, K. The Analysis of Fractional Differential Equations. An Application-Oriented Exposition Using Differential Operators of Caputo Type; Springer: Berlin/Heidelberg, Germany, 2010.

58. Kilbas, A.A.; Srivastava, H.M.; Trujillo, J.J. Theory and Applications of Fractional Differential Equations, Volume 204; Elsevier Science, B.V.: Amsterdam, The Netherlands, 2006.

59. Isaaks, E.H.; Srivastava, R.M. An Introduction to Applied Geostatistics; Oxford University Press: New York, NY, USA, 1989.

(C) 2020 by the authors. Licensee MDPI, Basel, Switzerland. This article is an open access article distributed under the terms and conditions of the Creative Commons Attribution (CC BY) license (http://creativecommons.org/licenses/by/4.0/). 